\title{
UNIVERSITY OF MICHIGAN
}

\author{
THE ROLE OF LETTERS OF CREDIT \\ IN PAYMENT TRANSACTIONS
}

Ronald J. Mann

UNIVERSITY OF MiCHIGAN

LAW SCHOOL

PAPER \#00-002

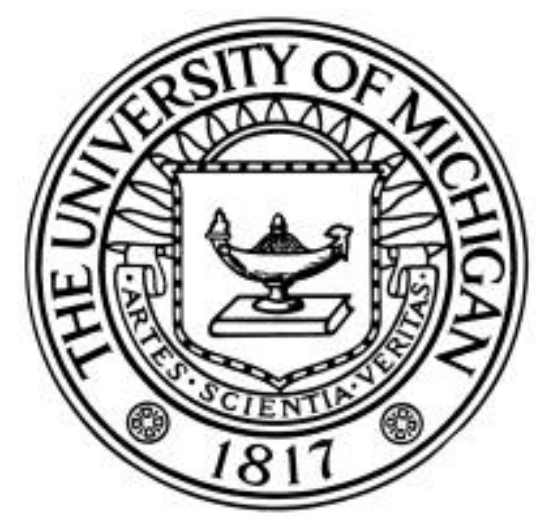

This paper can be downloaded without charge at:

The Social Science Research Network Electronic Paper Collection:

http://papers.ssrn.com/paper.taf?abstract_id=214633 


\title{
THE ROLE OF LETTERS OF CRED IT IN PAYMENT TRANSACTIONS
}

\author{
Ronald J. M ann* \\ Table of Contents
}

I. The Basic L etter -of-Credit Transaction ............................................... 0000

II. Discrepancies in L etter-Of-C Redit Transactions.......................................0000

A . The $\mathrm{N}$ ature of the $\mathrm{D}$ iscrepancies...................................................... 0000

1. What A re the Discrepancies? ...................................................... 0000

2. When D o D iscrepancies A ppear? ................................................. 0000

B. Waiving Discrepancies.................................................................... 0000

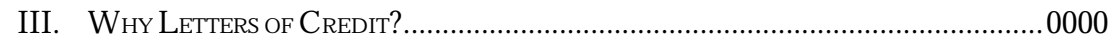

A. The R oad N ot Taken: Irrational H abit and Path D ependence ..................0000

B. The Classic Story: A ssurance of Payment............................................ 0000

C. The Letter of Credit as a V erification Institution.....................................0000

1. Verifying the Likelihood that the Buyer Will Pay ..............................0000

2. Verifying the A uthenticity of the Transaction.................................0000

IV. CONCLUSION ....................................................................................... 0000

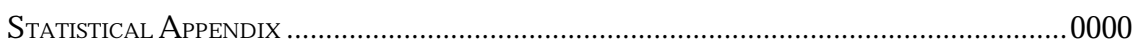

* (c) 1999 by Ronald J. M ann. Professor of L aw, The U niversity of M ichigan Law School. B.A. 1982, Rice; J.D. 1985, U niversity of Texas. - Ed. I dedicate this article to A lexandra Zoë M ann. I thank the individuals who took time from their busy schedules to allow me to interview them about letter-of-credit practices; I am particularly grateful to the institutions that kindly allowed me to collect information from their letter-of-credit records. Because that information was colected subject to a variety of confidentiality requirements, I regret that I cannot thank either of those groups by name. I also thank Jim Barnes for his gracious efforts to help me arrange my site visits and Atsushi Kinami for his similarly diligent efforts to arrange my interviews with J apanese bankers.

I received useful comments from each of the commentators and several other participants at the F ebruary 2000 M ichigan Law Review Symposium on Empirical Research in Commercial Transactions (for which this paper was prepared); I single out D ouglas Baird for a particularly generous investment of time and intellectual engagement with the ideas presented in the paper. I also received useful comments on earlier drafts from Buddy Baker, J im Barnes, Omri Ben-Shahar, D an K eating, Rick L empert, Vincent M aulella, Petr O berding, A riel Porat, A dam Pritchard, Bob Rasmussen, M ark West, and Jay W estbrook. David M urrel provided assi stance with graphics, Chris K illen, Catherine L eggieri, and Paula Payton with transcription of the interviews, and Scott $\mathrm{N}$ elson with a variety of research and logistics-related matters. Finally, I acknowledge with gratitude the generous research support of the R obert P. Tiernan F aculty Endowment F und at the U niversity of M ichigan Law School.

For convenience, all citations to provisions of the U niform Commercial Code without indication of date refer to the current version (that is, taking account of revisions made in 1999). Similarly, I refer throughout to international Chamber of Commerce, Uniform Customsand Practice for Documentary Credits (1993) (ICC Publication N 0. 500) as the U CP. 


\section{$* * * * *$}

Common justifications for the use of the letter of credit fail to explain its widespread use. The classic explanation claims that the letter of credit provides an effective assurance of payment from a financially responsible third party. In that story, the seller - a Taiwanese clothing manufacturer, for example - fears that the overseas buyer - Wal-M art - will refuse to pay once the goods have been shipped. Cross-border transactions magnify the concern, because the difficulties of litigating in a distant forum will hinder the manufacturer's efforts to force the distant buyer to pay. ${ }^{1}$ The manufacturer-seller solves that problem by obtaining a letter of credit from a reputable bank. A reputable bank is unlikely to default on its obligation to pay the seller, and the seller knows that it has an absolute right to payment once it ships the goods - conditioned only on the seller's presentation to the bank of the specified documents (typically the invoice, a packing list, an insurance certificate, and a transport document such as a bill of lading). Thus, the story goes, the seller that obtains a letter of credit can rest assured that it will be paid even if the buyer would not pay voluntarily. ${ }^{2}$

The payment-assurance explanation tells a logical and plausible story. But it rests on a line of reasoning that is largely untrue at one important and critical point: the seller's possession of an absolute right to payment. When I spoke anecdotally to bankers and lawyers familiar with the industry, they uniformly claimed that sellers ordinarily do not present documents that conform to the requirements of the letter of credit. A mong other things, documents might be missing, late, or fail to precisely match the details about the shipment provided in the letter of credit. 3

Under the standard payment-assurance account, the whole transaction hinges on the seller having a reliable right to payment by the bank that issues the letter of credit. But if the seller often does not submit documents that conform to the letter of credit, then the seller has no right to payment at all, just a request for a payment that will be honored only if the buyer waives the defects in the seller's presentation. 4 And if the seller's ability to collect rests on the buyer's unconstrained choice to

1. Lisa Bernstein's paper in this symposium also focuses on the special difficulties of cross-border sales transactions. See Lisa Bernstein, Private Commercial Law in the Cotton Industry: V alue Creation Through Rules, N orms, and Institutions, 98 M ICH. L. REV. ????, ????-???? (2000).

2. I myself have told that story. See Ronald J. Mann, PAyment Systems And Other Financial TRANSACTIONS 215-24 (1999). For similar accounts in the standard sources, see J OHN F. DOLAN, THE LAW OF Lettersof Credit: Commercial and Standby Credit 1 1.01[3], at 1-7 (rev. ed. 1999); Clayton P. Gillette et AL., Payment Systemsand Credit Instruments 560 (1996); James J. White \& Robert S. Summers, Uniform COMMERCIAL CODE § 20-1, at 701-02 (4th ed. 1995).

3. For published references to the discrepancy problem, see Vincent M. M aulella, Payment Pitfalls for the Unwary: H ow to M akeY our Letter of Credit W ork, W ORLD TRADE, A pr. 1999, at 76, 76 ("U S bankers report that $50 \%$ to $60 \%$ of all letter of credit document presentations are found discrepant on first examination."); M artin Shaw, M artin Shaw Claims There A re Better W ays to Reduce D iscrepancies and That ICC Should Take A dvantage of Them, D OCUMENTARY CREDITS INSIGHT, Spring 1999, at 11 (reporting the views of "informed observers" that "at least $50 \%$ - some say perhaps $60 \%$ or even $70 \%$ " of presentations do not comply); see also U CP preface, at 4 ("Some surveys indicate that approximately fifty per cent of the documents presented under the D ocumentary Credit are rejected because of discrepancies or apparent discrep ancies.").

4. See UCP art. 14(c) (authorizing issuer of letter of credit to approach applicant to seek a waiver of discrepancies in presentation). 
waive defects in the seller's presentation, then why buy the letter of credit instead of the simpler (and presumably cheaper) course of shipping the goods and simply waiting for payment from the buyer?5 ${ }^{5}$ That parties to a sale transaction would ignore formal documentation requirements is not surprising, but their systematic purchase of a product conditioned on their compliance with requirements they commonly ignore does not appear rational.

Intrigued by that question, I explored the topic in detail in the summer of 1999. I gathered data in two ways. First, I visited five separate banks on-site to collect data on their letter-of-credit transactions. Although all of the banks are located in the U nited States, I selected institutions of sufficient variety to get a representative picture of the industry as a whole. I visited the following banks: (a) a large U.S. regional bank headquartered in the $\mathrm{M}$ idwest with significant letter-of-credit volume; (b) a mid-sized U.S. regional bank headquartered in the N ortheast with significant letter-of-credit volume; (c) a major U.S. domestic bank headquartered in the W est with worldwide letter-of-credit operations; (d) a major foreign bank, with more than one U.S. location and with worldwide letter-of-credit operations; and (e) a major U.S. bank headquartered in the $\mathrm{N}$ ortheast with worldwide letter-of-credit operations. ${ }^{6}$ A t each bank I personally collected information on 100 transactions (50 "import" transactions, in which the bank's client was the buyer, and 50 "export" transactions, in which the bank's client was the seller). ${ }^{7}$ For each transaction, I recorded 25 data points. ${ }^{8}$ A mong other things, I determined whether the presentation conformed to the letter of credit and, if it did not, what the discrepancies were, and the parties' response to them. ${ }^{9}$ As a matter of practicality, I relied entirely on the banks' internal documentation of those issues. The banks, of course, could have erred in their assessment of discrepancies, but given the point of my study - understanding how parties react to discrepancies - data regarding their perception of discrepancies is directly relevant.10

\footnotetext{
5. For a brief description of the principal alternate methods of payment, seeinfra pages 421-423.

6. In order to obtain access to the banks' files I had to agree not to disclose the particular banks that I visited.

7. The transactions were selected to provide a random sample of recently completed transactions. Because the object of my study is to examine discrepancies in presentations, I excluded files in which the seller never presented a demand for payment under the letter of credit. A Iso, to avoid oversampling particular transactions, I only collected one profile from each file (even if the file included numerous presentations on a single letter of credit). A t each bank I continued to select files until I had a total (not counting the excluded files) of 50 import and 50 export transactions.

8. The information - about 12,500 data points - is in a M icrosoft A ccess database. Copies of that file are available on request.

9. I also collected a variety of background information: whether the letter of credit was confirmed, the countries in which the buyer and seller were located, the time when payment was due under the letter of credit, whether the letter of credit permitted multiple draws, the type of goods covered by the letter of credit, how the applicant paid the issuer for drafts on the letter of credit, whether the discrepancies suggested a contractual default, whether the discrepancies appeared to be curable, how the export-side bank responded to the documents, whether an export-side bank missed discrepancies that an import-side bank found, how waiver of discrepancies was sought, and how many days elapsed before the applicant waived the discrepancies.
}

10. In any event, it would not have been possible to reexamine the documents; in most cases the original documents (which often include transport documents that the buyer must use to obtain the merchandise in question) no longer were in the file. 
To supplement the raw data, I also interviewed ten bankers who engage in letter-of-credit transactions.11 I interviewed five of the bank officers who supervise the sites that I visited and five officers at other banks with substantial letter-of-credit portfolios (two other large A merican banks, and three Tokyo-based Japanese banks).12 Those interviews explored the significance of discrepancies in letter-ofcredit transactions.

Part I of this A rticle briefly describes the basic letter-of-credit transaction. Part II describes the discrepancies that appear in those transactions, providing detail from the data I collected. The data generally support the anecdotal information that led me to conduct the study: the documents presented in the 500 transactions I examined conformed to the letter of credit only $27 \%$ of the time. The payment transactions rendered the discrepancies irrelevant because the buyer waived the discrepancies in all but one case and provided full payment for the shipment in spite of the discrepant presentation. ${ }^{13}$

Part III uses the data and the interviews described above to assess the possible reasons for the common use of letter of credit. First, I reject the possibility that businesses use letters of credit out of irrational habit or custom because the ready availability and frequent use of alternative payment transactions strongly suggests that businesses rationally use letters of credit. Second, I evaluate the persuasiveness of the classic payment-assurance story and conclude that the payment-assurance story probably still has some plausibility, at least in contexts (such as many exports from the U nited States) where parties select the letter of credit to compensate for the weakness of relational ties between the buyer and the seller.

Finally, I consider some alternative reasons that might motivate commercial enterprises to use letters of credit. Specifically, I argue that the issuing bank's ability to verify information about the purchaser and the transaction provides the most compelling reason for widespread use of letters of credit. The issuer verifies information about the purchaser and the transaction in two ways. In the first and principal scenario, commonly used in situations where the parties have no significant relationship, the willingness of the bank to issue the letter of credit signals to the potential seller that the purchaser will not withhold payment for illegitimate reasons. In the second scenario, the bank's willingness to issue the letter of credit verifies to the government (or another fnancial institution) the legitimacy of the transaction, and the letter of credit indirectly assists in the enforcement of currency controls and laws against money laundering.

Those two explanations share a common and obvious thread: the problem of information asymmetry. In both situations, the parties design a transaction to include a letter of credit to respond to an information imbalance at the time the

11. Transcripts of the interviews (redacted to satisfy confidentiality requirements) are available on request.

12. The two A merican interviews were conducted by telephone; the J apanese interviews were conducted in person in Tokyo. The two interviews with A merican banks were conducted on condition of anonymity. Two of the Japanese banks were Fuji and Sumitomo; the third interview was conducted on condition of anonymity.

13. Even in that one case (Profile 457), the seller did not refuse payment entirely, but authorized a discounted payment of $94 \%$ of the amount upon which the parties originally had agreed. 
transaction begins. Thus, to use my own terminology, I argue that the letter of credit generally serves as a verification institution to resolve that information problem. ${ }^{14}$

\section{TheBasic L etter-of-Credit Transaction}

This study focuses on the basic commercial15 letter-of-credit transaction. That transaction has two sides: an import side (the buyer) and an export side (the seller). Both sides ordinarily have a bank, which makes a total of four parties to the transaction. The bank on the import, or buyer's, side of the transaction normally issues the letter of credit, which obligates the bank to pay the purchase price upon the receipt of specified documents.16 Letter-of-credit rules typically describe the importer as the applicant and the applicant's bank as the issuing bank or the issuer of the letter of credit.17 The fees differ significantly from market to market, and from customer to customer (with better customers paying much less). As a general matter, however, the total fees for the banks issuing and processing the letter of credit are likely to approximate $1 / 4$ of one percent of the amount of the letter of credit. On a $\$ 1,000,000$ sale of goods, then, use of a letter of credit would require about $\$ 2,500.18$ Figure $O$ ne illustrates the typical transaction.

\section{FIGURE 1}

14. For a general discussion of verification institutions, see Ronald J. M ann, Verification Institutions in Financing Transactions, 87 GEORGETOWN L.J . 2225 (1999).

15. The reference to "commercial" letters of credit limits my study to letters of credit used to provide payment in the ordinary course of a contract for the sale of goods. I exclude the other principal type of letter of credit, the "standby" letter of credit often used to provide a secondary means of payment when an obligor defaults on some other obligation. See DoLAN, supra note 2, 凤 1.04, at 1-20 to 1-24 (discussing the distinction between commercial and standby letters of credit); M ANN, supra note 2, at 372-73 (same). For the sake of comparison, I did, however, collect information at two banks on discrepancies in standby letter-of-credit transactions. M y data on that point, however, are much more limited (only 24 files) because it is quite rare for presentations to be made against the kind of standby letters of credit described above. \{Presentations are common against so-called "direct-pay" standbys, see DoLAN, supra note 2 , 1 1.06, at 1-45 \& n.170, but I excluded those transactions from the sample that I examined.\} Those data are included in the same database as the principal data.

16. See UCC $\S 5-102(a)(10)$ (defining a letter of credit as an undertaking to pay in response to a documentary presentation); see also UCC $\S 5-108(\mathrm{~g})$ (authorizing the issuer to "disregard" any nondocumentary conditions in a letter of credit); U CP art. 13(c) (same).

17. See U CC §5-102(a)(2) (defining "applicant" for purposes of letter-of-credit law); U CC § 5-102(a)(9) (defining "issuer" for purposes of letter-of-credit law); U CP art. 2 (defining "A pplicant" and "Issuing Bank" for purposes of the UCP).

18. See MANN, supra note 2, at 217. 


\section{Issuing the Letter of Credit}

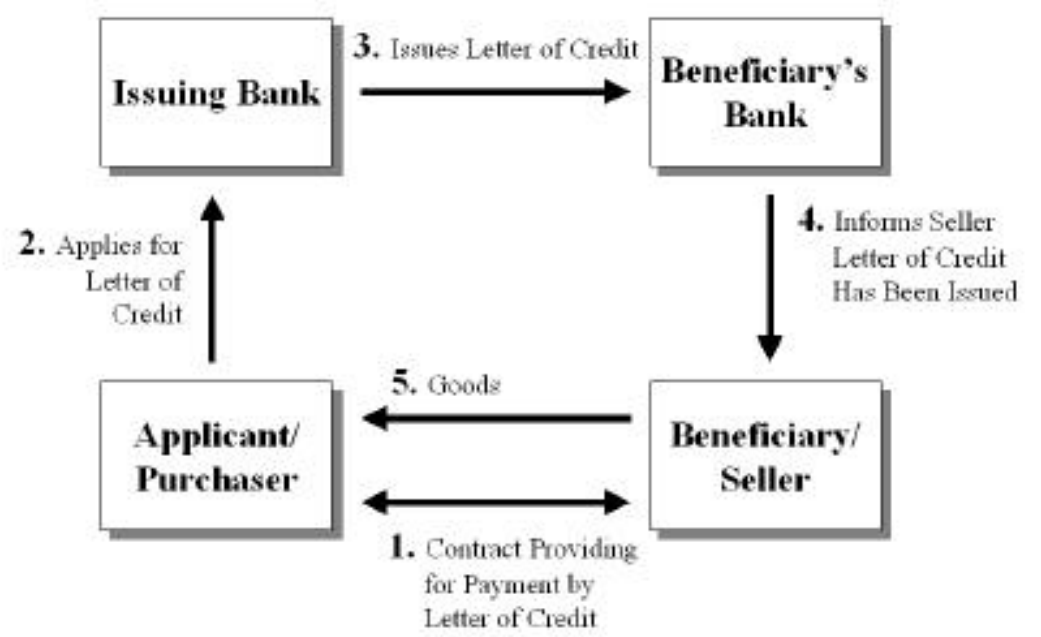

Central to the letter-of-credit system is the concept of indepen dence: the bank's obligation on the letter of credit is completely separate from any of the contractual obligations of the underlying transaction, either the obligation of the buyer to pay the seller under ordinary principles that govern sales transactions, or any obligation that the buyer might have under an agreement or common-law principles to reimburse the bank for payments made on its behalf under the letter of credit.19 The bank's obligation depends entirely on the beneficiary's presentation of documents that conform to the requirements of the letter of credit.20 Indeed, the rules governing letters of credit so thoroughly separate the bank's obligation to pay from ordinary context-laden principles of contract law, that it is best thought of, to use Roy Goode's apt term, as an "abstract payment undertaking" - an enforceable undertaking to make payment wholly abstracted from the underlying transaction.21

19. In the U CC's language:

Rights and obligations of an issuer to a beneficiary ... . under a letter of credit are independent of the existence, performance, or nonperformance of a contract or arrangement out of which the letter of credit arises or which underlies it, including contracts or arrangements between the issuer and the applicant and between the applicant and the beneficiary.

U CC § 5-103(d); see U CP art. 3(a) ("Credits, by their nature, are separate transactions from the sales or other contract(s) on which they may be based and banks are in no way concerned with or bound by such contract(s), even if any reference whatsoever to such co ntract(s) is included in the C redit.").

20. See UCP art. 4 ("In Credit operations all parties concerned deal with documents, and not with goods, services and/ or other performances to which the documents may relate."). N either the U CC nor the U CP requires any particular documents to be presented; each letter of credit describes the documents to be presented. It is quite difficult to generalize, but a typical list would include, among other things, an invoice, packing list, insurance certificate, some transport document (such as a bill of lading), and often some form of inspection certificate.

21. See Roy Goode, A bstract Payment U ndertakings, in ESSAYS FOR PATRICK A TIYAH 209, 209-13 (P. Cane $\&$ J. Stapleton eds. 1991). For a more readily available explanation of the point, see Roy Goode, A bstract 
The bank on the export, or seller's, side plays a different role. The seller hopes to receive the funds offered by the letter of credit as payment for the anticipated shipment, and is thus identified as the "beneficiary" of the letter of credit.22 Because the beneficiary and applicant ordinarily are in different countries, ${ }^{23}$ the beneficiary often has its own bank to help process the letter of credit when it is issued by the applicant's bank overseas and then forwards the documents that seek payment from the issuer when the seller ships the goods. ${ }^{24}$ The beneficiary's bank ordinarily assumes one of two roles. ${ }^{25}$ If it only "advises" the beneficiary of the issuance of the letter of credit, it just processes the documents and has no direct liability on the letter of credit.26 Alternatively, it might "confirm" the letter of credit, in which case the beneficiary's bank directly obligates itself on the letter of credit, ${ }^{27}$ pays the beneficiary directly, and then forwards the documents to the issuer for reimbursement. ${ }^{28}$ Figure 2 illustrates the payment process.

FIGURE 2

Payment U ndertakings and the Rules of the International Chamber of Commerce, 39 ST. LoUIS U. L.J . 725, 731-35 (1995).

22. See UCC §5-102(a)(3) (defining "beneficiary" for purposes of letter-of-credit law); U CP art. 2(i) (defining "Beneficiary" for purposes of the UCP).

23. The goods were shipped from one country to another in all but $51(10.2 \%)$ of the files. Even that figure may be distorted by an unusually high rate of same-country files at the bank that I refer to as the $M$ ajor $\mathrm{N}$ ortheast Bank (33 of the 51 same-country shipments). Excluding the M ajor N ortheast Bank, the rate of same-country shipments was only $4.5 \%$.

24. The beneficiary presented documents directly to the issuer, without retaining its own intermediary financial institution, in only $15(3 \%)$ of my files. A gain, that rate may be distorted by an unusually high rate of direct presentation files at the $\mathrm{M}$ ajor $\mathrm{N}$ ortheast Bank (9 of the 15 direct presentations). Excluding the $\mathrm{M}$ ajor $\mathrm{N}$ ortheast Bank, the rate of direct presentations was only $1.5 \%$.

25. The beneficiary's bank is described in the statute as a "nominated person," that is, a person that the issuer permits to process documents from the beneficiary and obtain payment from the issuer. U CC §5102(a)(11).

26. See U CC § 5-107(c); U CP art. 7(a).

27. See UCC § 5-107(a); UCP art. 9(b). In the 250 export-side files that I examined, the beneficiary's bank confirmed the letter of credit in $55(22 \%)$ of the files.

28. The U CC grants that right of reimbursement indirectly. U CC Section 5-108(i)(1) grants the issuer a right of reimbursement against the applicant; U CC Section 5-107(a) states that the confirmer has the same rights against the issuer as the issuer has against the applicant. See M ANN, supra note 2, at 230-31. 


\section{Payment by Letter of Credit}

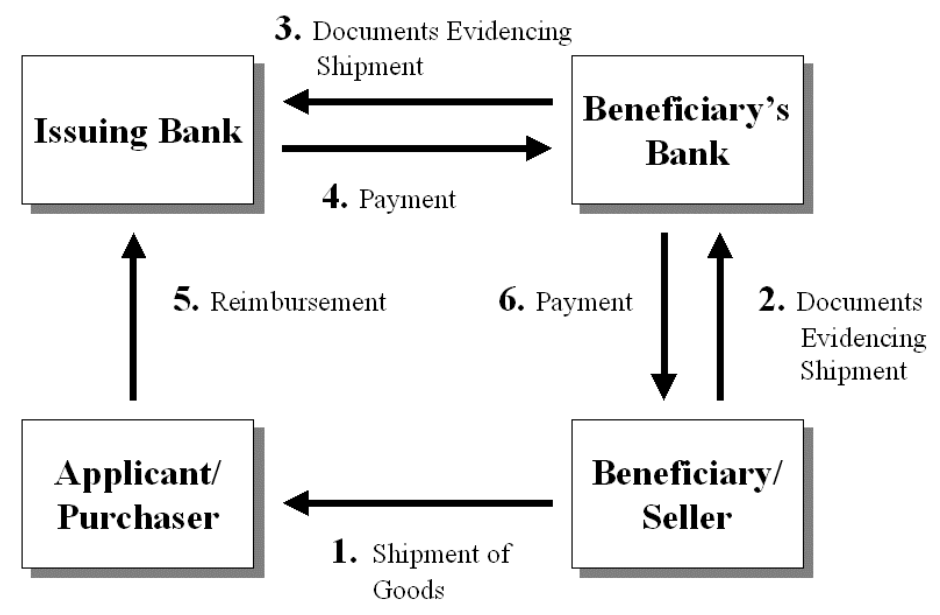

II. Discrepanciesin Letter-of-Credit Transactions

I set out to collect information about discrepancies in the presentations that beneficiaries make seeking payment on commercial letters of credit. Accordingly, I start by describing what the data suggest about those discrepancies. The data, of course, can only suggest explanations, because I did not collect information from a statistically valid sample of all letter-of-credit transactions. Although I collected my data from banks of varying sizes and types, the broad inter-bank variations within the data indicate that a complete picture of discrepancies would require a larger study based on a statistically valid sample drawn from a broader range of transactions.

Nevertheless, the consistency of certain patterns provides considerable information about the dynamics of commercial letter-of-credit transactions and how they can function with such high rates of discrepancies. I first discuss the discrepancies themselves; then I turn to the response of the applicant to the discrepancies.

\section{A. The $N$ ature of the $D$ iscrepancies}

As expected, the data illustrate a high rate of discrepancies: the presentations conformed to the letters of credit in only 135 (27\%) of the 500 files. A lthough the 
rates did differ from bank to bank - with a high of $36 \%$ and a low of $17 \%^{29}-$ conforming presentations provided the exception to a general pattern of discrepancy. The data offer considerable detail about the types of defects and the types of transactions where they frequently occur. Accordingly, I discuss those topics in turn.

\section{What A re the $\mathrm{D}$ iscrepancies?}

The data reveal the surprising severity of the discrepancies and, in my mind, rebut any suggestion ${ }^{30}$ that the high discrepancy rates reported by anecdote and found in the files arise from hypertechnical document examination practices. ${ }^{31}$ First, more than a quarter of the presentations that contained discrepancies (98 out of the 343 files, $29 \%)^{32}$ appeared to suggest a contractual default by the seller - not just a failure to comply with the technical provisions of the letter of credit, but a failure to comply with the substantive provisions of the underlying sales contract. ${ }^{33}$

29. The conformity rates were $26 \%$ at the $M$ idwest Bank, $17 \%$ at the $M$ id-Sized $N$ orth east Bank, $29 \%$ at the W est-Coast Bank, $27 \%$ at the F oreign Bank, and $36 \%$ at the $M$ ajor $N$ ortheast Bank.

30. See, e.g., Boris Kozolchyk, The UNIDROIT Principles as a Model for the Unification of the Best Contractual Practices in the A mericas, 46 AM . J . Com P. L. 151, 160-61 (1998) (arguing that "arbitrary" judicial evaluations of discrepancies "had encouraged bad faith practices by bankers and their customers whereby meaningless defects in the documents tendered by beneficiaries were used to justify non-payment of letters of credit").

31. Clay Gillette suggests in his comment on this article that bankers have an incentive to classify documents as discrepant to protect themselves against claims by their customers of wrongful honor. See Clayton P. Gillette, Comment on Ronald M ann's The Role of L etters of Credit in Payment Transactions, 98 M ICH . L. REV. ????, ????-???? (2000). One difficulty with that view is that it ignores the likelihood - which I consider quite strong - that bankers want to avoid an appearance of unduly strict document examination because undue strictness undermines their apparent willingness to stand behind the letters of credit that they issue.

M oreover, if he is correct, bankers should support relatively vague standards for document examination. Cf., e.g, Ehud K amar, A Regulatory Competition Theory of Indeterminacy in Corporate Law, 98 CoLUM. L. REV. $1908,1927-40$ (1998) (presenting an analogous argument that the interests of D elaware corporate lawyers are advanced by indeterminacy of legal rules). In fact, although the examination practice might seem hypertechnical to the outsider, A merican banks have expended considerable effort to enhance the objectivity of document examination. The bankers might be suffering from false consciousness, but they certainly believe that objectivity in examination standards furthers their interests, primarily by making it easier to identify bad actors (so that reputational sanctions can root them out). The most recent effort is illustrative, the promulgation of a detailed document (used at all of the banks that I visited) describing the items that banks should check on the most commonly presented types of documents. See U.S. CounCIL ON INTERNATIONAL Banking, In C., Standard Banking Practice for the Examination of LetTer of Credit Documents (1996); see also Boris K ozolchyk, The "Best Practices" A pproach to the U niformity of International Commercial Law: The U CP 500 and the NAFTA Implementation Experience, 13 ARIZ. J. NT'L \& COMP. L. 443, 446-48 (1996) (discussing development of the U SCIB standards). As doubts about the standards for document examination overseas suggest (see, e.g., infra notes $47 \& 50$ ), it is not at all clear that those efforts have made significant progress overseas.

32. Although 365 files failed to comply, 22 of those files were not even examined: in those cases the applicant approved payment without the need for examination of the documents. Thus, the information that I report about the types of defaults states percentages as a share of the 343 examined files found to be discrepant.

33. As mentioned in the introduction, I relied entirely on the banks' assessment to determine what discrepancies existed. See supra text accompanying note 10. I had to judge for myself, however, whether the discrepancies suggested a contractual default, something that was not always clear. I made a judgment call at the time I examined the file as to whether I thought the discrepancies collectively raised a serious doubt about 
M oreover, although the relatively subjective problem of defective documents arose frequently, 34 a large number of the non-contractual defaults were plainly objective defects upon which no informed document examiner could disagree. For example, 75 of the presentations (22\%) did not contain a document required by the letter of credit; 62 (18\%) involved a shipment later than the period specified in the letter of credit; in 48 (14\%) the beneficiary presented documents late 35 ; in 36 (11\%) the letter of credit had expired 36 ; and in $16(5 \%)$ the documents sought payment for an overdraft (an amount that exceeded the balance remaining on the letter of credit). ${ }^{37}$

Table One: Types of Discrepancies

$\begin{array}{lc}\text { D efective D ocuments } & 293(85 \%) \\ \text { M issing D ocuments } & 75(22 \%) \\ \text { Late Shipment } & 62(18 \%) \\ \text { Late Presentation } & 48(14 \%) \\ \text { Expired } & 36(11 \%) \\ \text { Overdraft } & 16(5 \%) \\ \text { Incorrect Shipment } & 14(4 \%) \\ \text { Partial Shipment } & 7(2 \%) \\ \text { Other } & 2(1 \%) \\ \text { Total D iscrepancies } & 554 \\ \text { Total DiscrepantFiles } & 365 \\ \text { Files N otExamined } & 22 \\ \text { Files Examined } & 343\end{array}$

Those discrepancies, however, do not generally suggest a serious failure of performance by the seller on the underlying sales contract; in 201 of the files (59\%), the defects found on examination did not suggest a contractual default by the

the performance by the seller. Because I was interested in the frequency with which technical defects that do not go to the seller's performance appear as discrepancies, I tried to err on the side of assuming that there might be a d efault.

34. D efects in documents collectively constituted the largest category of discrepancy, appearing in 293 $(85.4 \%)$ of the files. It is particularly difficult to determine whether defective documents suggest a contractual default, because it is rarely possible to tell from the file whether the defect reflects inadequate performance or inadequate documentation of ad equate performance.

35. U nless the letter of credit stipulates otherwise, documents must be presented no later than 21 days after the date of shipment. UCP art. 43(a). It was not common for the parties to alter that 21-day period in the letters of credit that I examined.

36. In addition to the implied deadline for presentation mentioned in the previous note, each letter of credit includes an express date on which the credit expires. A ny later presentation is defective. UCP art. 42(b); sæ U CP art. 44(a) (implied extension of expiration date to next business day).

37. In assessing those numbers, it is important to remember that many presentations contained multiple defects. Thus, the figures in the text count most of the files multiple times (because discrepant files often contained multiple defects, 554 defects in 343 examined files with discrepancies). 
beneficiary. ${ }^{38}$ Those defects, although often objectively indisputable problems with the presentation, do not suggest default because they involve minor documentary defects such as an inadequate signature on a bill of lading or a technical inaccuracy in describing the collateral, to name two common examples; or other defects of presentation rather than performance - late presentation (48 files, 14\%), 39 expiration ( 36 files $(11 \%)$, or overdraft ( 16 files, $5 \%$ ).

\section{Table Two: Discrepancies and Contractual Default}

$\begin{array}{ll}\text { D iscrepancies Indicating D efault } & 98 / 343(29 \%) \\ \text { Discrepancies N ot Indicating D efault } & 201 / 343(59 \%) \\ \text { Residual (U nable to Classify) } & 44 / 343(13 \%)\end{array}$

The data highlight one structural difficulty with the letter-of-credit system. If the system worked perfectly, documentary presentations would sort transactions based on the beneficiary's performance: the documents would comply when the beneficiary had performed as agreed and the documents would not comply when the beneficiary had not performed as agreed ${ }^{40}$ As the data show, however, more than half of the files included defects that vitiated the beneficiary's right to collect payment, even though those same defects did not call into question the caliber of the beneficiary's performance on the contract. A s industry observers recognize, the poor fit between discrepancies and default suggests a problem with the letter-ofcredit system. ${ }^{41}$

\section{When D o D iscrepancies A ppear?}

Even a casual examination of the data suggests that the discrepancies do not appear uniformly throughout the transactions. Dividing the files into import and export transactions provides the most apparent distinction.

As discussed above, each transaction has an import side and an export side. Because I collected information about transactions with the banks on both sides, I can explore the possibility that discrepancy rates relate to the role played by the bank. The rate of discrepancies might relate to the bank's role because a bank on the import side normally reviews documents that the beneficiary's bank has al ready

38. A s mentioned above (supra note 33), I treated ambiguous cases as suggesting a default. Thus, that $59 \%$ figure is, if anything, understated.

39. Late presentation (which I did not treat as a contractual default) must be distinguished from late shipment, which I did treat as a contractual default.

40. I leave to one side the question whether the performance that the system seeks is performance up to standards set by unenforceable industry norms or performance up to the standards of judicially enforceable contractual provisions. For discussion of the distinction between those two different types of standards, see Bernstein, supra note 1 .

41. See Shaw, supra note 3, at 11-12. Bob Rasmussen has pointed out to me that the poor fit is less relevant if you accept the idea (proposed in Part III of this A rticle) that letters of credit operate primarily as a device for verifying the reliability of the applicant rather than as a device for assuring payment. In any event, analysis of that problem is far beyond the scope of this A rticle. 
evaluated. All other things being equal, that relationship would suggest a lower rate of discrepancies on the import side of the transaction than on the export side: the beneficiary's bank should weed out defective documents in some class of cases, so that they would not even forward the most obviously defective documents to the issuer. Similarly, the beneficiary's bank could help the seller to correct simple discrepancies. As a result of those processes, an issuer - acting on the import side of the transaction - would receive a "cleansed" pool of documents to review, with a lower rate of discrepancies than it would find in documents it reviewed from the export side of transactions.

\begin{tabular}{|c|c|c|}
\hline & $\begin{array}{c}\text { NUMBER OF } \\
\text { DISCREPANCIES }\end{array}$ & $\begin{array}{l}\text { PERCENTAGE OF } \\
\text { DISCREPANCIES }\end{array}$ \\
\hline Import Transactions & $196 / 250$ & $78 \%$ \\
\hline Export Transactions & $169 / 250$ & $68 \%$ \\
\hline Overall & $365 / 500$ & $73 \%$ \\
\hline
\end{tabular}

At first glance, however, my data seem to contradict that understanding, because the import-side files contained a significantly higher rate of discrepancies ( $78 \%, 196$ out of 250 files) ${ }^{42}$ than the export-side files ( $68 \%, 169$ out of 250 files). ${ }^{43}$ On the other hand, the data about the activities of export-side banks suggest that export banks do cure discrepancies. As I mention above, the beneficiary's banks identified discrepancies in 169 of the 250 sets of documents submitted to them. But the export-side banks obtained complying documents in 68 (40\%) of those 169 files, leaving discrepancies in only 101 files. Thus, the beneficiary's banks were able to forward documents that complied in a total of $149(60 \%)$ of their 250 transactions.

The higher concern about documentary compliance exhibited by A merican banks and exporters provides the most salient explanation for these figures. ${ }^{44}$

42. Because I do not have access to the files of the export-side bank that handled the import-side files that I examined, I do not know what the rate of discrepancy was when the documents originally were presented by the customers in those transactions; I know only the rate of discrepancy that persisted after processing by the export-side bank, as evidenced by the documents reviewed by the import-side bank. The rate of discrepancy identified in the text does not change significantly even if I exclude the fifteen direct presentations (as to which the "cleansing" hypothesis is not relevant). All of the direct presentations (obviously) were import transactions (because the beneficiary-seller came straight to the issuer without using an intermediary export-side bank). Excluding those transactions (five of which nvolved conforming documents), the import discrepancy rate would have been $79.1 \%$ (186 out of 235 ).

43. The difference in the proportion of discrepancies between the two sides is significant at the .01 level. See infra Statistical A ppendix.

44. Indeed, more than one banker suggested that in A sia banks offer a standard product in which the seller agrees up front that its bank will not examine the documents, but instead will forward them immediately to the issuer without determining whether they comply. See N otes from Site Visit to Foreign Bank, at 1 (A ug. 26, 1999 - A ug. 27, 1999) [copy on file with author] [hereinafter Foreign Bank Site Visit Notes]; N otes from Site Visit to M idwest Bank, at 4 (July 28, 1999 - July 29, 1999) [copy on file with author] [hereinafter Midwest Bank Site Visit Notes]. It is not likely that the pattern that I discern is permanent. M ore than one banker suggested that a reverse pattern - more compliant documents coming into the U nited States than going out - was characteristic in earlier years. See Telephone Interview with 
Comparing the $22 \%$ rate ${ }^{45}$ of incoming conforming documents (documents that A merican issuers receive from overseas export-side banks) to the $60 \%$ rate of outgoing conforming documents described in the preceding paragraph (documents that A merican export-side banks transmit to overseas issuers) demonstrates this concern most starkly. ${ }^{46}$ Contrasting the domestic figures with the rate of complying documents forwarded by overseas banks further reinforces the higher regard that A merican banks and sellers have for producing compliant documents. The $22 \%$ figure of incoming compliant documents, which includes both initially compliant documents and initially defective but cured documents, is less than either (I) the rate of initially defective documents cured by A merican export-side banks (40\%, 68 out of 169) or (II) the rate of initially compliant documents submitted by exporters in this country $(32 \%, 81$ out of 250$)$.

\section{TABLe F OUR: ImPORT AND EXPORT COMPLIANCE}

$\begin{array}{lcc} & \begin{array}{c}\text { NUMBER OF } \\ \text { COM PLYING FILES }\end{array} & \begin{array}{c}\text { PERCENTAGE OF } \\ \text { COM PLYING FILES }\end{array} \\ \text { Import Compliance Rate } & 54 / 250 & 22 \% \\ \text { Total Export Compliance Rate } & 149 / 250 & 60 \% \\ \text { Initial Compliance (by Customers) } & 81 / 250 & 32 \% \\ \text { Cured (by Bank) } & 68 / 169 & 40 \%\end{array}$

Although a variety of considerations doubtless contribute on a country-bycountry basis to the differing rates of attention to discrepancies, the interviews with bankers suggest that the relative reliability of the A merican commercial and

M anager, Trade Service I ssues, Second M ajor N ortheast Bank (Sept. 21, 1999) [transcript on file with author] [hereinafter Second M ajor N ortheast Bank Telephone Interview] (transcript at 5-6); T elephone Interview with Vice President and Operations M anager, W est-Coast Bank (A ug. 12, 1999) [transcript on file with author] [W est-C oast Bank Interview] (transcript at 4); see also Interview with Y utaka A be, Senior M anager, O verseas Business Division, The F uji Bank, Limited, Tokyo (J une 15, 1999) [transcript on file with author] [hereinafter Fuji Bank Interview] (transcript at 3) (suggesting that discrepancies formerly were much higher in J apanese import transactions than they are now).

45. That rate is simply the flip side of the $78 \%$ discrepancy rate in import-side transactions. I also should emphasize that the rate differs considerably from bank to bank. In my data, it varied from $72 \%$ to $82 \%$. One other A merican banker with a large portfolio told me that the discrepancy rate in his import portfolio was only $60 \%$. Second $M$ ajor $N$ ortheast Bank Telephone Interview, supra note 44 (transcript at 2). It also varies significantly from customer to customer. O ne banker explained that although some of his customers submitted documents that complied $99.9 \%$ of the time, others submit documents that are discrepant $90 \%$ of the time. Second M ajor $\mathrm{N}$ ortheast Bank Telephone Interview, supra note 44 (transcript at 15); see also $\mathrm{M}$ aulella, supra note 3 ("[S]ome exporters report that over $95 \%$ of the document presentations are in order; other exporters report a $95 \%$ frustration rate.").

46. Again, because I do not have access to the files of the export-side banks in my import-side transactions, there always is the possibility that those banks had a systematically different view of the rate of discrepancy in the documents that I transmitted. See infra note 50 (discussing anecdotal evidence related to document-examination practices in J apan). To make any sense of the practice, however, I have to use some baseline for compliance and given data collected only from $U$ nited States banks it makes sense to use $U$ nited States document-examination practices as a baseline. Responding to that concern, I hope to collect similar data in J apan later this year. 
banking systems is the leading general cause. They explain it as follows: the party sending goods into the U nited States tends to worry less about the likelihood of misconduct by the U nited States purchaser than a corresponding United States exporter considering the likelihood of misconduct by an overseas purchaser. ${ }^{47}$ Indeed, the same idea supports the notion that letters of credit on shipments into the $U$ nited States serve a different function (unrelated to the reliability of the $U$ nited States buyer ${ }^{48}$ ) from the function that they normally serve on shipments out of the U nited States (where the reliability of the overseas buyer might be central to the use of the letter of credit).49

This explanation does not ring true with all countries with trading partners of A merican companies, but it likely covers many less-developed countries with relatively unstable economic conditions and undeveloped legal systems. Together, those conditions can make the reliability of the letter of credit less crucial for the party selling goods into the U nited States than for the party selling goods out of the U nited States. A ccordingly, the A merican exporter sending goods overseas (and its bank) will work harder to ensure that they have complied with the conditions of the letter of credit than an overseas exporter sending goods into the U nited States (and its bank). 50

Indeed, the interviews suggest that in many countries the export-side bank transmitting goods into the U nited States will not even bother to examine the documents before forwarding them. ${ }^{51}$ Thus, in those cases the bank makes no effort

47. See W est-C oast Bank Interview, supra note 44 (transcript at 7) ("O ur whole setup is based on not sending documents out of here which a bank overseas can find discrepancies with. . . because we know that in some areas of the world it's a tendency to find discrepancies for the sole purpose of coming up with a discount."). Interestingly, one banker suggested that banks follow country-by-country conditions so closely that they step up the vigilance of their document checking in countries (such as A sian countries in recent years) that appear to be undergoing particular crises. See Telephone Interview with Vice President, Bank N umber 1 (A ug. 6, 1999) [transcript on file with author] [hereinafter M idwest Bank Interview] (transcript at 12-13). A s he explained, although the banks in the country under stress might honor discrepant documents $99 \%$ of the time under normal conditions, "in hard times they might reject half of them." Id. (transcript at 13).

48. See infra section III(C)(2).

49. See infra section III(C)(1). I thank Bob R asmussen for pushing me to see that point.

50. Some loose evidence of the less stringent document-review practices overseas seems to be apparent from the perception of J apanese banks that there is a very low rate of discrepancy in the documents they receive from their clients in export transactions. See Interview with Deputy General M anager (Special A ssignments), D eputy G eneral M anager, and Senior M anager, A nonymous J apanese Bank, Tokyo (J une 17, 1999) [transcript on file with author] [hereinafter A nonymous Japanese Bank Interview] (reporting a discrepancy rate on export transactions of only 35\%); Interview with Hiroshi Higuma, A ssistant M anager, Corporate Planning Dept., The Sumitomo Bank, Limited, Tokyo (J une 21, 1999) [transcript on file with author] [hereinafter Sumitomo Interview] (transcript at 3) (reporting a discrepancy rate on export transactions of only $15 \%$ albeit after cure efforts at the branch-bank level\}).

Those rates suggest to me that a considerably different standard for document examination prevails in Japan than the one that prevails in A merican banks reviewing documents received from Japan. As it happens, my information on documents coming into this country from J apan (4 of the $13 \mathrm{~J}$ apan-based import transactions $\{31 \%$ \} included complying presentations) is too limited to support any inferences about those practices. M oreover, even if I examined J apanese transactions at a J apanese bank it would not provide direct evidence of the relative rigor of their document examination practices. The most obvious test would require using A merican-trained examiners to study a set of documents also submitted to J ap anese examiners; that type of test is not practical with the logistical resources available for my research.

51. See supra note 44 and accompanying text (mentioning references to that practice). 
at all to cure discrepancies, a far cry from the apparent A merican banking practice of scrutinizing documents and curing about $40 \%$ of the discrepant documents submitted by their customers.52

Because I did not examine export-side transactions in the files of any overseas banks, I have no direct observations of their effort (or lack of effort) to cure defective documents. I can, however, compare the frequency that documents with curable defects were not cured in transactions coming into and going out of the U nited States.53 The 250 export transactions included 236 transactions outbound from the U nited States, of which 36 (15\%) included curable discrepancies that were not cured. By contrast, the 250 import transactions included 178 transactions inbound to the U nited States, of which 79 (44\%) included curable discrepancies that were not cured. ${ }^{54}$

The variety of explanations offered by the bankers suggests the need for considerably more data to explain the phenomena persuasively. For example, one banker pointed to the differing types of typical credits for the two sets of transactions: incoming shipments into the U nited States are much more likely a part of substantial long-term relationships (as to which discrepancies are less important $)^{55}$ while outgoing shipments from the U nited States are much more likely "one-off" transactions where the shipper enjoys limited relational protections. ${ }^{56}$ A nother banker offered a different transaction-based explanation: price changes that make opportunism more beneficial occur more commonly with commodities shipments (which characterize transactions going out from the U nited States) than on manufactured-goods shipments (which characterize transactions coming into the

52. Clay Gillette suggests in his comment on this article that the high rate of uncured defects is unsurprising, reasoning that buyers easily could cure the defects in the rare case in which a seller is intransigent. See Gillette, supra note 31, at????-????. In most cases, however, that would be impractical. For one thing, no amount of effort could cure a presentation that involves a late shipment, late presentation, or expired letter of credit. At least one of those defects appeared in - of the 343 discrepant files that I examined. Furthermore, because documents ordinarily must be presented no more than 21 days after the shipment (see U CP art. 43(a); supra note 35), and because documents ordinarily are presented quite close to the presentation deadline in the first instance, it seems most unlikely that a buyer in any significant group of cases could (a) present discrepant documents; (b) await rejection by the seller; (c) cure the discrepancy; and (d) still represent compliant documents before expiration of the 21-day time frame.

53. At the time I examined the files I included for each file a notation reflecting my judgment as to whether it was easily practicable for the benefici ary or the beneficiary's bank to cure the defect in question.

54. I use the total number of transactions as the denominator, rather than the number in which discrepant documents initially were presented, because I do not know the number of the import transactions in which discrepant documents initially were presented.

55. A s suggested above, see supra text accompanying nn. 48-49, that thesis gains some support from the analysis in Part III(C)(2), which outlines several country-specific reasons why export transactions from the U nited States might use letters of credit in continuing rel ationships, even though there is good reason to think that exporters generally use letters of credit less often in continuing relationships, see infra pages 423-423 (discussing the possible inverse connection between letters of credit and the strength of the buyer-seller relationship).

56. See Midwest Bank Interview, supra note 47 (transcript at 11-12); see also Interview with Vice President and M anager, International Operations, Bank N umber 2 (A ug. 5, 1999) (location not disclosed to protect anonymity) [transcript on file with author] [hereinafter Mid-Sized Northeast Bank Interview] (transcript at 12) (explaining that relational considerations are the prime motivation for buyers to waive discrepancies in documents presented for payment on letters of credit). 
U nited States).57 I did not collect sufficiently objective data on the types of goods covered by the shipment to evaluate that thesis statistically, but outgoing (commodities) shipments would plausibly have higher price fluctuation than incoming (finished goods) shipments.

57. See Second M ajor $N$ ortheast Bank Telephone Interview, supra note 44 (transcript at 6 ). 
FIGURE 3

\section{Figure 2}

Discrepancy Rates in Commercial Letter-of-Credit Transaction Inbound to United States

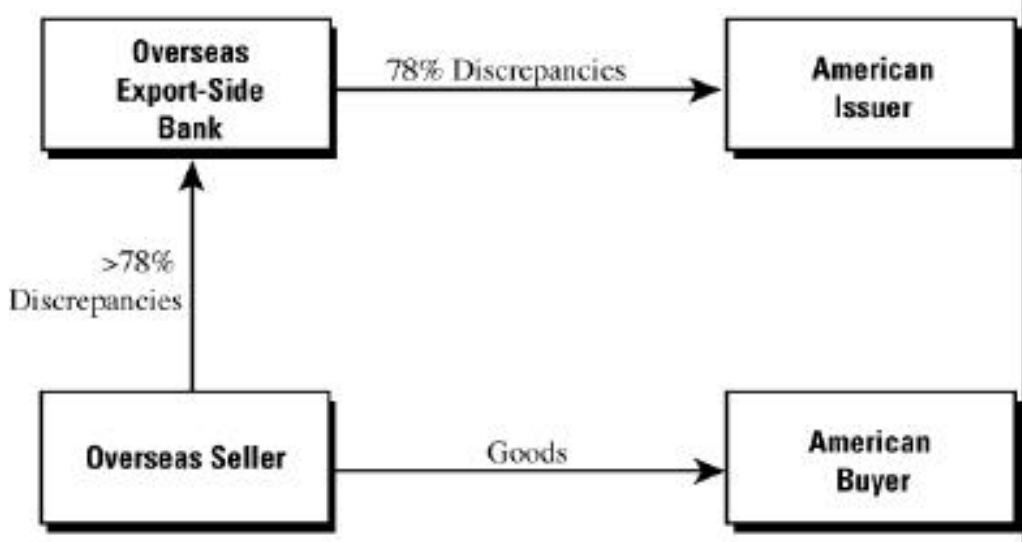

Outbound from United States

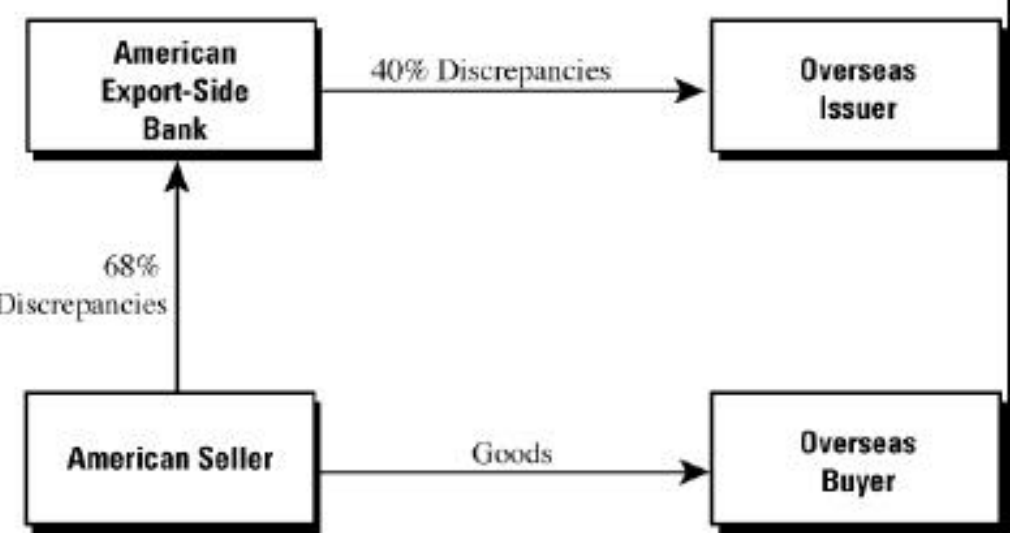


Summarizing, Figure Three illustrates the most likely explanation of the data - the existence of four different rates of discrepancy. In transactions exporting goods from the U nited States, beneficiaries submit discrepant documents about $68 \%$ of the time, and cure efforts of banks lower the discrepancy rate to about $40 \% .58$ In transactions importing goods into the U nited States, parties make little effort to cure defects, so that the initial presentation discrepancy rate probably 59 is about the same as the $78 \%$ discrepancy rate in documents forwarded to U nited States issuers.60

\section{B. Waiving Discrepancies}

Because the frequency of discrepancies motivated this study, the information described above was not entirely surprising; it confirmed anecdotal descriptions with an added wealth of detail that serves as fodder for new speculation. The response to the defaults was the most surprising. I expected to find that applicants seize on the discrepancies in a significant number of cases - including many cases in which the discrepancies did not suggest a contractual default - as a basis for delaying or withholding payment to the beneficiary on the letter of credit. ${ }^{61}$

The data suggest that my expectation was wrong: even when the documents suggest a default on the underlying contract, applicants almost always waive the discrepancies and permit full payment to the beneficiaries under the letter of credit. In the 365 files with discrepancies, the applicants waived the discrepancies and permitted full payment in every file but one. And in that file the applicant did not

58. The limited evidence that I collected in J apan does not robustly support that understanding of the A merican data. Because J apan has an economy that resembles the A merican economy in what seem to be all relevant respects, I would have expected the data from J apan to resemble the data from the U nited States on this point. As it happens, however, the anecdotal information from J apanese bankers indicated that the rate of discrepancies in transactions coming into J apan, although much less uniform, was relatively low. See Fuji Bank Interview, supra note 44 (transcript at 3) (20-30\% discrepancy rate on J apanese import transactions); Sumitomo Interview, supra note 50 (transcript at 2) (25\% discrepancy rate on J apanese import transactions). Somewhat inconsistently with the other data, another J apanese bank (on condition of anonymity) reported a discrepancy rate on import transactions of $67 \%$. A nonymous J apanese Bank Interview, supra note 50 (transcript at 2-3). As suggested above, however, the lower Japanese discrepancy figures also might be attributable to differing standards of document examination. See supra note 50. I hope to collect more data in $J$ apan this fall to provide some understanding of the relevant country-specific differences.

59. Because I did not examine export-side transactions in the files of any overseas banks, I have no direct observation of that rate.

60. That two-tiered understanding of my data is corroborated by a similar (although slightly more discrepant) set of figures provided to me under condition of anonymity from a banker at a major $\mathrm{N}$ ortheastern bank. His data suggested that the highest rate of discrepancy ( $60 \%$ in his portfolio) is on incoming import transactions, that there is a lower discrepancy rate $(50 \%)$ on outgoing export transactions, and that his bank cures about half ( $25 \%$ ) of the export discrepancies before the documents are forwarded overseas. See T el ecopy from Second M ajor N ortheast Banker 1 (Sept. 21, 1999) [copy on file with author].

61. M y expectation was supported by the views of the drafters of the $U C P$, who report that "[s]ome surveys indicate that approximately fifty percent of the documents presented under the D ocumentary Credit are rejected because of discrepancies or apparent discrepancies." UCP preface, at 4. In hindsight I can make that statement correct by interpreting the reference to "reject[ion]" to mean only a determination of discrepancy, but before I did this study I interpreted it to mean rejection in the sense of refusal to accept. 
refuse payment, it permitted payment of $94 \%$ of the agreed amount.62 Thus, in the 500 letter-of-credit transactions examined, the applicant never refused payment on the letter of credit. ${ }^{63}$ The data doesn't vary from assertions by bankers involved in the industry; every interview subject with whom I spoke about payment refusal claimed that applicants would refuse payments in less than one percent of the discrepant files. ${ }^{64}$

Even more surprising than the rate of waiver was how quickly applicants waived defaults. Several bankers suggested that applicants - even if they ultimately permit payment - commonly delay payment for a significant period of time to reflect dissatisfaction with the beneficiary's performance in the transaction. But the data suggest that applicants generally waived promptly. Of the $196 \mathrm{import}$ files with discrepancies, the applicant in more than half of the files - 103 (53\%) waived the discrepancies within one business day after the issuer contacted the applicant about the discrepancy. By one week after the issuer contacted the applicant, they waived discrepancies in 165 (84\%) of the files. ${ }^{65}$ By four weeks after the issuer contacted the applicant, only six files (3\%) remained unaccepted.

62. Profile 457. That transaction included some defects that did not demonstrably indicate contractual defaults expiration, late presentation, a missing document (one counterpart of a purchase order), and a defective document (technically inaccurate shipping terms). It also included, however, a late shipment, which normally would reflect a default on the underlying contract.

63. In all of my files, the banks immediately paid upon receipt of the waiver. It is, however, the view of the industry that the bank is not bound by the waiver issued by its customer the applicant. See ICC, M ORE QUERIES AND RESPONSESON U CP 500: 1997, at 14 (1997) (Response 254) (“In the event that discrepancies are observed in a presentation of documents and the issuing bank [gives adequate notice of the discrepancies], the issuing bank is under no obligation to take up the documents, even if a proper waiver of the discrepancies is received from the applicant."); ICC, M ORE QUERIESAND RESPONSES ON U CP 500: 1997, at 28 (1997) (Response 267) ("The receipt of a waiver from the appli cant, either direct or via the beneficiary, does not bind the issuing bank to accept the documents. The decision of whether or not to comply with the waiver is one for the issuing bank to decide in its sole judgment."). It appears that the only substantial reason that a bank would decline to accept such a waiver would be doubts about its ability to obtain reimbursement from the applicant. See Second M ajor N ortheast Bank Interview, su pra note 44 (transcript at 6-7).

64. See Foreign Bank Site Visit $\mathrm{N}$ otes, supra note 44 , at 1 (estimating three refusals each year out of 10,000 presentations, for a rate of .03\%); Telephone Interview with executive from Bank N umber 5 (0 ct. 8 , 1999) [transcript on file with author] [hereinafter M ajor Northeast Bank Interview] (transcript at 10) ("I would have said it was a small fraction of one percent." ); Telephone Interview with Vice President, Technical Consultant for Global Trade Services, Major Midwest Bank (J uly 19, 1999) (interview conducted on condition of anonymity) [transcript on file with author] [hereinafter $M$ ajor Midwest Bank Telephone Interview] (transcript at 7) ("I would say ninety-nine percent of the documents [that are discrepant are paid]."); Second M ajor N ortheast Bank Telephone Interview, supra note 44 (transcript at 5) ("[A ]t the end of the day ninety-nine point nine percent of the documents they present, whether they carry discrepancies or not, are paid."); Second M ajor N ortheast Bank Telephone Interview, supra note 44 (transcript at 17) (banker who does 100,000 transactions a year suggesting that "I would be very comfortable in just guessing [that the number of rejected documents per year is] less than a hundred. It may be less than ten."); W est-C oast Bank Interview, supra note 44 (transcript at 7) (agreeing with my expectation of finding only one or two refused presentations in my five-hundred file study).

The pattern appears to be similar in J apan. See A nonymous J apanese Bank Interview, supra note 50 (transcript at 7) (suggesting rejection of about ten documents out of a monthly volume of 17,000 transactions); F uji Bank Interview, supra note 44 (transcript at 9) (reporting rejection of documents or reduction of amount to be paid in about ten out of every 18,000 transactions); Sumitomo Interview, supra note 50 (transcript at 4) (suggesting rejection of ten documents out of a monthly volume of one thousand noncomplying transactions).

65. One week (five business days) serves as a rough guide of a timely response, because the issuer generally needs to respond to the bank that presented the documents within seven business days after it receives the documents. See U CP art. 13(b) (calling for a response within "a reasonable time, not to exceed 
A s a practice of accommodation in transactions among long-time partners, the rate and pace of waivers might seem commonplace. But as we see below, many letters of credit are used in one-shot transactions or other contexts where relational constraints have less force, precisely because of the lack of confidence in the relationship. 66 In those contexts, that rate of waiver seems truly startling.

\section{W hy Letters of Credit?}

The data presented in Part I display an odd and puzzling picture. Commercial parties pay substantial fees to banks to use letters of credit in their transactions. ${ }^{67}$ The beneficiaries then usually submit documents that do not conform - which jeopardizes their right to payment under the letter - but the applicants then almost universally waive the defects with startling haste, notwithstanding the frequent contractual defaults displayed on the face of the documents presented by the seller.

The remainder of this Article offers some tentative explanations for that pattern. Given the worldwide use of the commercial letter of credit, and its use in a wide variety of contexts, no single explanation captures all of the motivations for its use. The information collected in this study does, however, allow me to make some progress in understanding the transactions. Thus, this Part of the Article begins in Section $A$ by rejecting the idea that businesses use letters of credit because of some sub-optimal path dependence or mistake. Section B then critically assesses the payment-assurance story, concluding that it cannot provide a general explanation, but likely continues to play some role, especially in relation-deprived uses of letters of credit. F inally, Section $C$ offers two new justifications for the use of letters of credit, both of which turn on the ability of the issuer to verify to a third party some present or future fact about the buyer or the transaction. N one of the explanations qualifies as a general, unified explanation for all of the transactions in which businesses use commercial letters of credit. Taken together, however, they provide a general picture of plausible motivations for much of the universe of commercial letter-of-credit transactions.

\section{A. The Road $\mathrm{N}$ ot Taken: Irrational H abit and Path D ependence}

Perhaps no rational explanation elucidates the puzzle presented by the high discrepancy rates: businesses use letters of credit not because of the benefits they

seven banking days"). If the issuer takes two business days to examine the documents, that would leave five business days for the appli cant to decide whether it wishes to waive any discrepancies without preventing the issuer from transmitting a timely acceptance of the documents. Of course, if the issuer does not receive a waiver by the seventh business day, it still can pay later, by sending a notice rejecting the documents on the seventh business day, followed by a later notice accepting the documents with discrepancies. For a thorough discussion of typical practice, see International Finance Services A sso ciation, Statement of Practice: Reasonable Time for Examination \& N otice of Dishonor, in The 1999 Annual Survey of Letter of Credit Law \& Practice 311 (J ames E. Byrne ed.) .

66. See infra pp. 423-423 (discussing reasons why parties select letters of credit instead of other payment mechanisms).

67. See M ANN, supra note 2, at 217. Because all methods of payment in cross-border transactions involve some out-of-pocket transaction costs, the excess cost of the letter of credit is a bit less than that $\$ 2,500$ figure. 
provide, but because of a combination of practical factors such as a failure to understand how letters of credit work in practice, along with some habit of usage. To put it more directly, that perspective suggests that businesses buy letters of credit from banks by mistake - because they always have - and that if they fully understood the costs and benefits of letters of credit they would use alternate payment systems.

The mistake story cannot be rejected out of hand: businesses cannot have perfect comprehension of everything that they do and surely they occasionally enter into transactions on terms attributable to imperfections in their understanding. ${ }^{68}$ But two factors make me doubt the general applicability of the mistake theory.

First, the sophistication of the parties involved reduces the credibility of the mistake theory. M any of the users of letters of credit are large and sophisticated companies. In the study, for example, I reviewed the files of several prominent discount retailers and department stores that obtained letters of credit to pay their overseas suppliers. And they did not use letters of credit occasionally or haphazardly; on the contrary, the files clearly documented that those companies have large letter-of-credit relationships covering a substantial portion of their sales activity. 69 A bsent some new evidence, it seems implausible that those companies would organize such a large number of transactions in a way that systematically, repeatedly, and pointlessly increases the cost of the transactions.

The larger framework of the institutions for providing payment in cross-border sales transactions also casts doubt on the mistake explanation, because it shows that businesses make a conscious and deliberate choice to select the letter of credit from among a variety of competing payment institutions. G enerally, sellers and buyers can choose from four significantly different methods of providing payment in crossborder transactions. Ranging from most favorable to the seller to most favorable to the buyer, the options include prepayment, payment by letter of credit, payment by documentary collection, and open account. ${ }^{70}$

The first and the last are the simplest and cheapest, but create the greatest possibility for opportunistic misconduct by the trading partner. In the prepayment transaction, the buyer forwards payment before the seller ships the goods. In the open-account transaction, the seller ships the goods without any formal assurance that the buyer will forward payment when the goods arrive. Thus, in each of those transactions one party first performs completely, trusting the other party to respond by performing in turn. ${ }^{71}$

68. For comments to that effect in this context, see F uji Bank Interview, supra note 44 (transcript at 1314) (discussing the lack of sophistication by smaller companies doing international trade and explaining that "there's a perception for the J apanese company that the LC is very credible, reliable. And once they receive an LC they feel like they have completed the transaction."); Second Major Northeast Bank Telephone Interview, supra note 44 (transcript at 15, 17) (suggesting that customers focus on the fact that their letter-ofcredit transactions get paid rather than the risk of nonpayment).

69. The size of such a relationship was particularly evident at two of the banks (Banks 1 and 4), whose file-numbering systems included a separate filing system - with separate numbers and file locations - for the transactions of two prominent retailers that are their largest letter-of-credit customers. Each of those customers provided, on a conservative estimate, more than $20 \%$ of the bank's letter-of-credit work.

70. See M id-Sized N ortheast Bank Interview, supra note 56 (transcript at 6-7).

71. See M id-Sized N ortheast Bank Interview, supra note 56 (transcript at 6). 
In between those two polar choices lie two intermediate choices, the letter-ofcredit and documentary-collection transactions. Those transactions intertwine the performance of the parties, with each party taking substantial steps toward performance before either party completes its activities. In the letter-of-credit transaction, as discussed above, the seller waits to ship until it receives a letter of credit issued on behalf of the buyer. The buyer, in turn, withholds payment until it receives adequate evidence that the shipment has occurred, as shown by the documents required for payment under the letter of credit.

The documentary-collection transaction (or, commonly, a collection transaction) is another intermediate option, cheaper but less protective of the seller than the letter-of-credit transaction. ${ }^{72}$ The seller ships the goods without any previous action by the buyer to effect payment, but a transport document transmitted through banking channels covers the goods. In the typical (though not universal) way of arranging the transaction, the buyer cannot obtain the document of title, and thus cannot obtain the goods that the document covers, until it pays the bank for the goods. ${ }^{73}$ The collection transaction favors the seller less than the letterof-credit transaction because the buyer has no obligation to take up the documents. ${ }^{74} \mathrm{H}$ ence, the buyer might not be able to get the goods without paying for them, but the seller cannot force the buyer to pay; if the buyer chooses not to pay, that the seller must deal with goods that it has shipped to an overseas location, with no local buyer for them..$^{75}$ The collection transaction provides a more secure option than an open-account transaction (where the buyer can get the goods without paying for them), but not by much. Collection transactions, however, cost much

72. F or a more detailed summary, see M AN N, supra note 2, at 457-66. For descriptions by a banker, see M id-Sized N ortheast Bank Interview, supra note 56 (transcript at 6-7). Because two of the banks that I visited maintained records on documentary-draft transactions at the same sites as they maintained letter-of-credit records, I collected information on documentary-draft transactions at those sites ( 50 records at each bank for a total of 100). Those records are in the same database as the other data.

73. See M id-Sized N ortheast Bank Interview, supra note 56 (transcript at 7 ("If the documents are titled properly then no pay, no documents for merchandise."). Two common variations use nonnegotiable documents of title. In one, the goods are consigned to the collecting bank; that has substantially the same effect as a negotiable shipment, because the buyer usually must pay to acquire the goods. See Mid-Sized N ortheast Bank Interview, supra note 56 (transcript at 8-9). The other common variation, particularly in shipments by air, uses nonnegotiable documents and ships directly to the buyer. In that transaction the buyer can obtain the goods without paying the bank for them. See M id-Sized N ortheast Bank Interview, supra note 56 (transcript at 8). Thus, that transaction provides the seller little more protection than the open-account transaction discussed above. The transactions proceeded in that less protective fashion in 33 out of the 96 (34\%) collection transactions for which I could examine the relevant documents.

74. See M idwest Bank Interview, supra note 47 (transcript at 8) (“[A ] collection raises the obligation of absolutely nobody to do anything that they don't want to do."); W est-Coast Bank Interview, supra note 44 (transcript at 13) ("[Y ]ou're completely putting yourself at the mercy of that party [i.e., the overseas buyer].").

75. See M id-Sized N ortheast Bank Interview, supra note 56 (transcript at 7). Buyers declined to pay the banks in 12 out of the 100 collection transactions. That $12 \%$ non-payment rate is striking compared to the non-payment rate in the letter-of-credit transactions of less than one-tenth of one percent. The higher nonpayment rate would not surprise the bankers to whom I spoke about colection transactions. See, e.g, M idSized N ortheast Bank Interview, supra note 56 (transcript at 12) (discussing difficulties of obtaining payment in collection transactions); W est-C oast Bank Interview, supra note 44 (transcript at 13-17) (same). 
less than a letter-of-credit transaction, with bank fees typically fixed in the range of $\$ 100-\$ 300$, regardless of the size of the transaction.76

The available information makes it clear that parties can realistically and freely choose among those four payment systems. Significantly, the choice suggests that the letter of credit is not the automatic response of a custom-bound industry. Businesses don't use letters of credit indiscriminately out of habit. Rather, they select them for transactions in which they do not have a good enough relationship with the overseas party to justify engaging in collection or open-account transactions. As one banker put it, "there has to be trust between the two before you send the documents on collection."77 Indeed, the best information I found indicates that businesses use letters of credit in only about one-fifth of cross-border sale-of-goods transactions coming into or out of the $U$ nited States.78

The relatively low rate of use certainly does not suggest a market populated by businesses that buy letters of credit for no good reason. On the contrary, it suggests a market in which businesses use cheaper methods of payment whenever the protections of the letter of credit fail to justify the cost, and, in which they select the letter of credit only when they want its security. G enerally, it suggests, businesses use letters of credit in one-shot transactions where relational protections are inapplicable, or in the opening stages of a potential long-term relationship, before relational constraints become effective.

\section{B. The Classic Story: A ssurance of Payment}

The payment-assurance story provides the classic understanding of letters of credit. In that story, the key benefit offered by the letter of credit is a right of

76. See M id-Sized N ortheast Bank Interview, su pra note 56 (transcript at 15-16) (discussing the different types of charges in letter-of-credit transactions and collection transactions); W est-C oast Bank Interview, supra note 44 (transcript at 12) ("[0 ]bviously the cost of a letter of credit is very much higher than a collection. O ur collection fees are low - very low in comparison. [Collections are not a big money maker and they're looked at more as a service to a customer instead of an actual money-making product."); see al so supra note 67 (discussing fees for letters of credit). [M y estimate of the fees for collection transactions is based on my review of the files in my database.]

77. M idwest Bank Interview, supra note 47 (transcript at 8); see M id-Sized N ortheast Bank Interview, supra note 56 (transcript at 19-20) (discussing reasons why parties choose collection transactions instead of letters of credit); W est-C oast Bank Interview, supra note 44 (transcript at 12) ("[T] ]he only reason [collection transactions] exist is because there's a great deal of .. . trust between the parties concerned or in some cases people just would rather take the risk than pay the initial letter-of-credit fees, which can get pretty expensive."). For a similar view from a knowledgeable academic, see J ohn F. Dolan, Letters of Credit: A Comparison of U CP 500 and the N ew U.S. A rticle 5, [1999] J. Bu S. L. 521, 528 ("Thus the commercial letter of credit arises most often between parties that know little of each other or are in distant markets and when at least one party is located in a developing country.").

78. One banker reported to me two sources of data in his possession. The data that he considered more reliable suggested that $13 \%$ of such transactions were done by letters of credit, $72 \%$ by open account, $4 \%$ by documentary collections, and $2 \%$ by cash in advance. A nother source (that he considered less accurate) reported $29 \%$ letters of credit, $52 \%$ open account, $12 \%$ cash in advance, and $7 \%$ documentary collections. See Interview with G roup Vice President and H ead of Trade Services Product M anagement, International Trade \& A dvisory Group, Bank N umber 4 (Sept. 2, 1999) (Iocation not disclosed to protect anonymity of bank) [transcript on file with author] [hereinafter F oreign Bank Interview] (transcript at 13). W hichever figures are closer to reality, however, both figures suggest that letters of credit are not used routinely without regard to cost. 
payment enforceable against the issuer. That right largely removes the risk of the open-account transaction - that the seller will ship its goods first and that the buyer, once in possession, will withhold payment from the seller. Put another way, the letter of credit exchanges the typically uncertain obligation of a buyer to pay for something received for an absolute obligation of a financial institution.

Part II demonstrates that the payment-assurance method fails to explain the general use of letters of credit. The payment-assurance story makes sense only if the seller generally expects to use the letter of credit to force the issuer to pay. But as the data suggest, an experienced seller would understand that it usually cannot force payment from the issuer, because it usually will not submit documents that comply with the letter of credit. Thus, in many if not most cases, the seller's right to payment will depend entirely - at least as a legal matter - on the grace of the buyer in waiving the discrepancies in the documents submitted by the seller.

To be sure, a weaker version of the payment-assurance story may supply a better fit with a high rate of discrepancies. For example, if letters of credit cost little, if sophisticated sellers expect buyers to renege and try to withhold payment quite rarely, and if it is expensive to submit documents that comply, then rational sellers might use letters of credit generally, but accept a high rate of discrepancy, just to keep the letter of credit in reserve for the rare cases in which buyers try not to pay.

Indeed, the information I collected about cure efforts suggests that I incorrectly assumed that high discrepancy rates are inconsistent with some payment-assurance rationale. M ost obviously, the existence of substantial cure efforts, illustrated by my discussion above of A merican export-side banks, ${ }^{79}$ indicates that exporters and the banks that serve them see significant value in producing documents that comply. Importantly, the rate of discrepancy correlates with a high degree of significance to the size of the letter of credit. ${ }^{80}$ If compliance of the documents was not significant, then parties would not try harder to produce compliant documents in larger transactions. ${ }^{81}$

The pattern of cure efforts underscores that correlation. On the one hand, although again based on the limited data in the study, the largest cure efforts appear in the context - exports from the U nited States to overseas buyers - in which parties generally use letters of credit to compensate for the absence of strong relations between the buyer and the seller. Conversely, cure efforts seem much weaker on imports into the U nited States. A gain, generalizing with caution, concerns about the reliability of the A merican importer might be less substantial. 82 Finally and most interestingly, the single context in which I saw parties dispensing entirely with cure efforts - purchasing letters of credit sold at a lower price and

79. See supra pp. 412-415.

80. The correlation is quite weak, but it is significant at the .007 level. See infra Statistical A ppendix.

81. It is possible that the documents required in larger transactions are simpler, and that the higher rate of compliance is a function of those easier requirements rather than greater compliance efforts. A s I state in the Statistical A ppendix, infra note 140, I do not have the data to test that question, but it does seem most unlikely to me.

82. I offer in section III(C)(2) a reason for letter of credit usage independent from those relation-based concerns. 
processed without any export-side review of the documents at all - involves transactions importing goods into the U nited States.83

To be sure, I cannot credit the payment-assurance effect as anything but a relatively weak factor. The large frequency of easily curable defects in the files that I examined suggests that it cannot be all that important to provide complying documents. D efects that the bank can cause the seller to cure generally could have been avoided more cheaply in the first place. To use a common example from the files that I examined, surely a seller would save money writing a draft correctly the first time rather than writing a defective draft, paying the bank's discrepancy fee, ${ }^{84}$ and then taking the time and effort a week later (after prodding by the bank) to produce a compliant draft. Even experienced and careful sellers would make mistakes from time to time, which banks would catch, but a universe in which banks can cure defects in more than one-fourth ( $27 \%, 68$ out of 250 export files) of the presentations made to them is not a universe populated by diligent sellers trying hard to avoid obvious mistakes.

In sum, I believe, again based on the limited data, that assurance of payment must remain part of the story of letters of credit, but that it provides an inco mplete reason for their use. To tell the whole story, we must look also for some other benefit to the seller that obtains a letter of credit.

\section{The Letter of Credit as a V erification Institution}

If the letter of credit adds real value to the underlying transactions, and if a right of payment enforceable against the issuer cannot explain the value, then the value must come from something else provided by the bank that issues the letter of credit on behalf of the buyer. A s a matter of transactional design, the bank provides some sort of "verification" of information that it can assess better than any of the other parties to the transaction. ${ }^{85}$ The points of difficulty lie in identifying precisely what the bank verifies and why the parties need the bank to verify it. Given the limited scope of the data collected to date (which includes no information about the nature of the customers or their relations with the banks or their transaction partners), I can only speculate at this point. Still, I can identify two separate justifications for use of the commercial letter of credit as a verification institution: verifying to the seller the likelihood that the buyer will pay and verifying to the government the legitimacy of the transaction.

\section{Verifying the Likelihood that the Buyer Will Pay}

In my view, the implicit verification of the applicant's reliability and probity that the issuer makes when it issues the letter of credit generally explains the

83. See supra note 44 (discussing that product as available to businesses shipping goods from A sia to the U nited States); infra note 132 (same).

84. At the banks that I visited, discrepant presentations universally were assessed a fee, which ranged from a low of $\$ 25$ to a high of $\$ 75$.

85. I organize my observations here using the framework I previously have developed to discuss thirdparty "verification institutions." Se M ann, supra note 14, at 2265-71. 
common usage of letters of credit. Structurally, that verification furnishes a classic example of reputational intermediation: the applicant/ buyer "rents" the issuer's reputation to allow the beneficiary/seller to verify the credibility of the applicant/ buyer's promise to make payment when the seller ships the goods.86

Central to that arrangement, of course, is the availability of a reputational sanction against the bank that issues the letter of credit. On that score, I take it as given that banks generally have a strong reputational interest in their letter-of-credit businesses.77 For that explanation to make sense, however, I need to examine three separate characteristics of the transactions in which the letter of credit is used: the relative ease of verifying the reliability of a foreign bank as opposed to a foreign trading partner; the plausibility of treating a bank that issues a letter of credit as vouching for the future performance of its client the applicant; and the information that the bank is in a position to provide. I address those problems in turn.

a. Why Evaluate the Bank Instead of the Buyer? The bank helps to solve the information problem that faces a seller of goods to a foreign buyer when the seller attempts to estimate the likelihood that the buyer opportunistically will attempt to withhold payment in the transaction after the seller ships the goods. Efforts to assess the reputation of the buyer directly often will be expensive and ineffective.88 For one thing, the buyer's location in a foreign country makes it more costly to collect information than if the buyer were located in the same country as the seller.89 As one banker put it, letters of credit are not as useful in same-country transactions because "it's easier to get a credit report cheaper than to force somebody to give them a letter of credit."90 Also, even if the information is available, it may be less reliable to the seller than information collected in the seller's own country. ${ }^{91}$ Similarly, differences in accounting systems from country to country generate difficulties in the assessment of any objective financial

86. The classic explanation of reputational intermediation appears in Ronald J. Gilson \& Reinier $\mathrm{H}$. K raakman, The M echanisms of M arket Efficiency, 70 VA. L. REV. 549, 618-21 (1984) (discussing reputational intermediation in the issuance of securities); see also $M$ ann, supra note 14, at 2269-71 (generali zing that idea).

87. The best anecdote I heard about the significance of bank reputation in the letter-of-credit context involved Chinese banks that were barred by the Chinese government from using hard currency to honor previously issued letters of credit. N otwithstanding the plenary control of the government over bank activities in mainland China, the officers at those banks still used a variety of arrangements - offsets against overseas funds and the like - to do the best they could to provide timely payment on the letters of credit that they had issued. See F oreign Bank Interview, supra note 78 (transcript at 3-4).

88. For a theoretical discussion of reasons why it is difficult for many countries to develop effective systems for disseminating credible information about their businesses, see Bernard S. Black, The Legal and Institutional Preconditions for Strong Stock M arkets: The N ontriviality of Securities Law (unpublished Sept. 1999 manuscript) [copy on file with author].

89. See Foreign Bank Interview, supra note 78 (transcript at 4) ("If you're selling to somebody outside the U nited States it's very difficult to get good credit information so you try to go to [D un \& Bradstreet] or whatever you can. But, you get very sketchy inform ation." ); M ajor N ortheast Bank Interview, supra note 64 (transcript at 7).

90. M idwest Bank Interview, supra note 47 (transcript at 5).

91. See Foreign Bank Interview, supra note 78 (transcript at 5) (pointing out that Dun \& Bradstreet collects information on foreign companies, but suggesting that "companies in another country are not so concerned [as A merican companies] about [the validity of the information that they provide Dun \& Bradstreet]"). 
information that the seller might obtain. M oreover, the sheer number of potential trading partners worldwide makes the task of maintaining any knowledge of financial strength and probity daunting at best.

Although those problems create similar difficulties in the assessment of the financial strength and credibility of foreign banks, foreign parties can much more easily evaluate foreign letter-of-credit banks than they can evaluate foreign trading partners. ${ }^{92}$ For one thing, the universe of reputable letter-of-credit banks is much smaller than the universe of trading partners: in most countries only a few banks participate in the global letter-of-credit arena. Thus, parties can obtain much more information about those banks. ${ }^{93}$ Second, large banks in the relevant markets more often follow internationally comprehensible accounting conventions than the great mass of trading businesses in the foreign country; thus, analysts in the seller's country can more easily assess information about the buyer's bank than information about the buyer itself. 94 Third, especially for smaller countries with less stable financial conditions, regulatory authorities more often provide close supervision of the affairs of banks than they do of the affairs of the large number of trading businesses in the country. ${ }^{95}$

Taken together, those conditions all work together to make it considerably easier for analysts in the seller's country to form a confident opinion of the reliability of the buyer's bank than of the buyer itself. That opinion can be in the formal nature of a published rating ${ }^{96}$ or it can be less formal periodic updates that a local bank provides its larger customers ${ }^{97}$ or even episodic comments about banks involved in particular transactions.98 Regardless of the opinion's form, parties

92. See Second M ajor N ortheast Bank Telephone Interview, supra note 44 (transcript at 14) (“W hen we're asked to confirm a credit - we're making that decision for the most part based on the bank. ... We understand the bank and we know the bank and we have a rel ationship with the bank and we may not have a relationship or know the importer.").

93. See Foreign Bank Interview, supra note 78 (transcript at 5) (“[T]here's an awful lot publicized. There's a lot you can read in The Economist or other periodicals, magazines, things about the creditworthiness of various banks and the countries that they're in.").

94. See Foreign Bank Interview, supra note 78 (transcript at 5-6) ("Banks are much more standardized in the way that they do their accounting. ... [T ]hey're also going to be doing a lot of international activities so there's going to be a lot of pressure on them from correspondent banks they are doing busi ness with to state their numbers according to generally accepted accounting principles.").

95. See Foreign Bank Interview, supra note 78 (transcript at 5) (“[I]t's also quite true that countries are very sensitive - or at least traditionally very sensitive - to keeping all of their banks running. So, as long as the country itself is in good condition it's very unlikely that a bank will go bankrupt... . [Y ]ou can't depend on that completely but it's a much better risk than a corporate risk."). That observation does not apply, of course, to the U nited States and other countries sufficiently confident in their financial systems to allow bank failures to provide market discipline. For discussion of some of the difficulties that regulators face in permitting bank failures, see Curtis J. M ilhaupt, Japan's Experience with Deposit Insurance and Failing Banks: Implications for Financial Regulatory Design? , 77 W ASH. U. L.Q. 399 (1999); Geoffrey P. M iller, Is Deposit Insurancelnevitable? Lessons from A rgentina, 16 INT'L REV. L. \& E CON . 211 (1996).

96. See F oreign Bank Interview, supra note 78 (transcript at 6) (discussing such a publication); M idwest Bank Interview, supra note 47 (transcript at 6) (discussing ratings agencies that rate foreign banks).

97. See Foreign Bank Interview, supra note 78 (transcript at 6) (discussing the availability of such updates)

98. See Foreign Bank Interview, supra note 78 (transcript at 6) (discussing the bank's willingness to provide that information); M id-Sized N ortheast Bank Interview, supra note 56 (transcript at 18) (describing requests for such information). The importance of reliable information is underscored by the common 
involved in letter-of-credit transactions maintain constant vigilance over the activities of the foreign banks with whom they deal,99 and that vigilance seems much more effective than any comparable monitoring of the actual trading partners. ${ }^{100}$

b. Does the Bank Vouch for the Buyer? Although a seller considering a transaction in a foreign country can verify the reliability of the foreign bank more readily than it can the reliability of the foreign merchant, what significant information about the foreign merchant does the foreign bank convey when it issues the letter of credit? A fter all, the foreign bank does not accept any financial responsibility for the actions of its customer, the buyer (except in the indirect sense that the bank is obligated to pay when the documents in fact comply). Specifically, and perhaps more to the point, the bank does not undertake even to encourage the buyer to waive any discrepancies that might undermine the bank's obligation to pay the seller for the shipment.

By the time I finished collecting the information for the study, I became persuaded that banks effectively vouch for their customers when they issue letters of credit for them.101 For one thing, some bankers directly stated that the bank's reputation was at risk whenever their customers refuse to waive discrepancies in presentations seeking payment on letters of credit.102 One explained:

[B]anks are very sensitive to their credibility. It doesn't mean they won't reject

practice of an A merican bank seeking confirm ation from another A merican bank of a letter of credit issued by an overseas bank with which the first A merican bank is not adequately familiar. See M id-Sized N ortheast Bank Interview, supra note 56 (transcript at 18-19); M idwest Bank Interview, supra note 47 (transcript at 6); see also $\mathrm{M}$ ajor $\mathrm{N}$ ortheast Bank Interview, supra note 64 (transcript at 4) (discussing the value to a Hong Kong bank of having a letter of credit issued by its $\mathrm{N}$ orth A merican correspondent).

99. See Mid-Sized Northeast Bank Interview, supra note 56 (transcript at 16-17) (discussing unwillingness to continue processing letters of credit issued by banks whose customers fail to waive discrepancies in a timely manner); Second $\mathrm{M}$ ajor $\mathrm{N}$ ortheast Bank Telephone Interview, supra note 44 (transcript at 13) (discussing calls from other bankers about the interview subject's willingness to confirm letters of credit issued by lesser-known foreign banks); W est-C oast Bank Interview, supra note 44 (transcript at 9-10) (explaining that confirmation by a U nited States bank of a letter of credit issued by a foreign bank with which he is not familiar would assuage concerns about the reliability of the foreign bank and its customer).

100. For that reason I am puzzled by Clay Gillette's argument in his comment on this paper that a system that can impose reputational sanctions on banks should be able to impose reputational sanctions on buyers as well. See Gillette, supra note 31, at????-????. A s I understand the dynamic, there are relatively few banks in the industry in each country and the banks serve as intermediaries on both sides of the transaction collecting information about the buyers for whom they issue letters of credit and about the banks whose letters of credit they process. I see no reason why the export-side bank should be lax in that process simply because it is an adviser rather than a confirmer - the exporting customer expects to get paid either way and will be unhappy if the overseas bank and its customer reject documents after the goods have been shipped.

101. See Foreign Bank Interview, supra note 78 (transcript at 5) (suggesting that issuance of a letter of credit provides a "credit reference" and agreeing that the reference extends not only to financial strength but also to general probity); M idwest Bank Interview, supra note 47 (transcript at 6) ("If you have an issuing bank that is of a certain reputation and class and standing it's not a difficult leap of faith to say that the customers that they're issuing letters of credits on behalf of - that. . . the customer is worthy of that extension of credit."); W est-Coast Bank Interview, supra note 44 (transcript at 10) ("[T]hat a bank in hdia will issue a credit for this importer ... says they must think highly of them.").

102. Foreign Bank Interview, supra note 78 (transcript at 7) (“W e're very uncomfortable whenever we do refuse a set of documents. So even though I guess we're pretty willing to find discrepancies and call a customer up and say, 'These are all the discrepancies,' . . . [w ]e want them to waive all those discrepancies. If they are going to refuse... . we want it to be based on good grounds for refusal."). 
documents when documents are presented that do not conform to the letter of credit. They'll do that but they're very sensitive about having the letters of credit not paid when they are supposed to be paid. 103

Indeed, several bankers - especially those to whom I spoke in Japan reported that they "persuade[d]" or "pressure[d]" their customers to waive the discrepancies in any case in which the seller's performance was not seriously defective. ${ }^{104}$

Several bankers, however, insisted that they would not engage in such efforts, pointing out that their customers are entitled to insist that the bank adhere strictly to the terms of the letter of credit.105 But a deeper examination of the practices of those bankers suggests that even they are vouching for their customers, albeit in a subtle and indirect manner.106 The dispositive point for me is the consistent statements of sophisticated letter-of-credit bankers that they will not issue letters of credit indiscriminately. All of the bankers with whom I discussed the topic agreed, in one way or another, that they engage in a serious screening process of customers for whom they issue letters of credit.107 Although the customer's ability to reimburse the bank for any payments that it makes on letters that it issues on the customer's behalf is necessary, it plainly is not sufficient: the process (like much of commercial banking) involves broader questions of general commercial probity and "character." 108 One banker put it aptly: "There's more than just the money. Y ou

103. M id-Sized N ortheast Bank Interview, supra note 56 (transcript at 17).

104. See A nonymous J apanese Bank Interview, supra note 50 (transcript at 5) (“[W ]e do not force them, but we ask them very persuasively to pay immediately."); F uji Bank Interview, supra note 44 (transcript at 10) ("To suspend the payment sometimes sends a negative message for the bank."); Fuji Bank Interview, supra note 44 (transcript at 11) (discussing efforts to persuade customers to waive defects); Sumitomo Interview, supra note 50 (transcript at 8) (" [I]f there is some slight discrepancy then of course we try to persuade them to pay for the draft."). I do not mean to suggest a peculiar J apanese attitude, only that the J apanese attitude differs from the A merican attitude. M y only possible source of direct information on the attitudes of bankers from countries other than the U nited States and Japan would be my work at foreign-owned banks in the U nited States. M y impression - which might be worth little - is that the foreign-owned banks that I visited were not substantially influenced in the "culture" of their letter-of-credit departments by their foreign ownership. It is true, however, that the only A merican banker willing to admit to a similar practice was at an A merican office of a foreign bank. He explained: "W e'd tell them that they're playing games and we've actually told customers to take their business elsewhere if they're going to do that. ... . So, we try to put as much pressure on them as possible and say, 'Y ou've got to pay.'" Foreign Bank Interview, supra note 78 (transcript at 9).

105. See M ajor M idwest Bank Telephone Interview, supra note 64 (transcript at 8) ("W e don't urge our clients to pay. That's the client's deci sion."); M id-Sized N ortheast Bank Interview, supra note 56 (transcript at 14); W est-C oast Bank Interview, supra note 44 (transcript at 3).

106. See F oreign Bank Interview, supra note 78 (transcript at 4) (describing the significance of " $[t]$ he fact that a bank is willing to issue a letter of credit for somebody"); W est-Coast Bank Interview, supra note 44 (transcript at 9) ("[T]he fact that a bank will issue a letter of credit tells me something about the credit standing of that customer which gives me a good feeling."). O ne banker agreed that many bankers make such a "quantum leap of faith," but that it is "unwarranted." He explained that point by identifying several reasons why one bank might be willing to issue a letter of credit for a weak applicant, which would not justify a second bank in relying on the applicant. Second M ajor N ortheast Bank Tel ephone Interview, supra note 44 (transcript at 13-14).

107. See, e.g., M idwest Bank Interview, supra note 47 (transcript at 7) ("[S]imply because somebody comes in and asks you to issue a letter of credit you're not going to do it.").

108. See M ajor N ortheast Bank Interview, supra note 64 (transcript at 4-5) (“U.S. banks in general will not deal with clients who are disreputable, who are dishonest, whose management is not known to them, who 
know, what's their performance history? W hat's their business history? W hat are their markets? . . . [T] ]here's a whole assessment done of the business aspects. ... It's not whether you have ten bucks to put up for the credit." 109

The behavior of banks backed up these statements; a bank that became convinced that a customer was acting opportunistically with respect to its trading partners would consider ceasing to issue letters of credit for that customer. M ore than one banker reported incidents in which the banker refused to continue dealing with major, profitable customers because of dissatisfaction with the business dealings of the customer. ${ }^{110}$ M ost importantly, several bankers acknowledged that one notable type of malfeasance that would undermine the willingness to continue a relationship would be a pattern of refusing to waive discrepancies in letter-ofcredit transactions ${ }^{111}$ that went beyond normal behavior for the particular industry in question 112 (with the garment industry being notorious for a custom of footdragging). ${ }^{113}$ One banker described a typical confrontation on that point as follows:

are in and out of bankruptcy, who are acting in an unethical and dishonest manner."); see also ERIC N. COMPTON , PRIN CIPLESOF BANKING 284 (1991) (discussing "the five C s of credit," the first of which is "character of the borrower").

109. M idwest Bank Interview, supra note 47 (transcript at 7).

110. See Foreign Bank Interview, supra note 78 (transcript at 10) (“[W ]e don't like doing business with people like that. W e sometimes get ourselves into big arguments with the relationship managers because they want to do thebusiness. ... [T ] hey say 'Oh, it's a great credit relationship.' A nd we say, 'W ell, tell them to take their letters of credit somewhere else then because we just don't want to be associated with people like this.' "); W est-C oast Bank Interview, supra note 44 (transcript at 11) ("In particular - I know that our people are very stringent on who they grant credit to because I've seen a lot of their customers leave or be asked to leave.").

111. See Second M ajor N ortheast Bank Telephone Interview, supra note 44 (transcript at 7) (explaining that the letter-of-credit department would bring to the attention of a client's relationship manager any pattern of delays in waiving discrepancies on letters of credit). For a similar sentiment from J apan, see A nonymous Japanese Bank Interview, supra note 50 (transcript at 11) (suggesting that his bank does not experience substantial problems with failure to waive discrepancies because of the quality of companies with which his bank deals).

112. A s more than one banker emphasized, some industries (most notably the garment industry, see infra note 113) are characterized by lengthy delays in waiver of discrepancies on letters of credit. But that does not mean that bankers are reluctant to issue letters of credit in that industry; rather, it means that they are more tolerant of delays than they would be in other industries. Even there, however, issuers would cease to do business with an otherwise profitable customer if it began imposing pre-waiver delays that were longer than customary. See M ajor N ortheast Bank Interview, supra note 64 (transcript at 5-6) ("If I saw a transaction that broke an industry pattern it would raise eyebrows, it would raise a red flag for me and I hope whatever bank that was involved that was handling it."); Second $M$ ajor $N$ ortheast Bank Telephone Interview, supra note 44 (transcript at 18-19) ("If we had an importer who was doing this [i.e., refusing to waive discrepancies in a timely manner] on a regular basis and it was outside the norm then I guess that would be it.").

113. It seems to be common in the garment industry for importers to delay their acceptance of discrepant documents by lengthy periods of time on the order of a month. See Major Northeast Bank Interview, supra note 64 (transcript at 1-3); Second M ajor N ortheast Bank T elephone Interview, supra note 44 (transcript at 18) ("W e have customers here who have money who I think will jerk beneficiaries around given the opportunity because it's the nature of the trade they're in. It's the nature of the rag business."); $N$ otes from Site Visit to Bank N umber 2, at 1 (A ugust 4, 1999 - A ug. 5, 1999) [copy on file with author]; W estCoast Bank Interview, supra note 44 (transcript at 3 ). Indeed, many bankers believe that garment-industry letters of credit are designed by the A merican importers to be especially complex for the purpose of enhancing the likelihood of discrepancies. See W est-Coast Bank Interview, supra note 44 (transcript at 8) (" $G$ armenttype credits are ... . notorious for discrepancies because of the text of the credits going out. They're so detailed with regard to merchandise description. It just gives an opportunity for greater mistakes to be made"). To be 
W e'd tell them that they're playing games and we've actually told customers to take their business elsewhere if they're going to do that. . . . So, we try to put as much pressure on them as possible and say, "Y ou've got to pay." And if they say "No, no, no I'm not gonna pay and I don't care what you say," we say, "W e don't want to do business with somebody like you." 114

Similarly, another banker talked at length about his unwillingness to issue letters of credit with "built-in" discrepancies - letters of credit that the seller could not possibly satisfy:

I tell you seriously, when we have clients, we have on occasion had discussions with clients who say "I want you to issue a letter of credit with built-in discrepancies because I want to make sure that the beneficiary cannot present documents and get paid immediately" and we decline to do that. And if they insist and threaten to close the account we will close the account for them because if they are going to act in that kind of a manner toward their trading partner overseas then what is there to make me think they will not act in the same unethical manner in their relationship with me their banker. I have been involved at this end with other banks where we literally have gone to a customer who's complaining because we're not putting built-in discrepancies in their letters of credit and have carried a check with me and closed their account on the spot. 115

c. What D oes the Bank's V erification Say A bout the Buyer? The last difficulty lies in identifying precisely what the bank implies (for it certainly states nothing expressly) about its letter of credit customers. It seems implausible that the bank offers something as imprecise as a general credit reference along the lines of "this is the kind of customer that always pays." If so, then we would expect to see an even smaller rate of nonpayment in the transactions in which buyers have graduated to documentary-collection transactions from letter-of-credit transactions.116 But my limited data suggests precisely the opposite: a nonpayment rate of about $10 \%$ in documentary-collection transactions ${ }^{117}$ compared to a nonpayment rate in letter of

sure, the limited willingness to accept discrepant documents is attributed in part to the greater likelihood that even slight delays in shipment or slight nonconformities of the product will have an effect on the underlying commercial transaction. For example, a fall line of clothes that arrives two months late in D ecember is more likely to have a diminished value than a part needed to repair a broken machine that arrives after a similar delay. See M id-Sized N ortheast Bank Interview, supra note 56 (transcript at 1-2).

The delays that those importers impose on discrepant documents usually are followed by waiver of the discrepancies and full payment on the letter of credit, but there also seems to be an expectation of negotiation outside the letter-of-credit process that might result in other concessions not apparent from the bank's files. See W est-Coast Bank Interview, supra note 44 (transcript at 3). M oreover, the delays that are typical for the industry appear to be taken into account in the pricing of the transactions in the first instance. See $M$ ajor N ortheast Bank Interview, supra note 64 (transcript at 6):

It is not up to me to determine what kind of a deal the buyer and the seller strike and when I started in this business 28 years ago, I was horrified to learn of some of these things until I discovered that, well yes, but in the rag trade coming from this part of the world that the vendors figure it's a forty-three day delay when they are dealing with Company $A$. They know that and they build it into their prices.

114. Foreign Bank Interview, supra note 78 (transcript at 9).

115. M ajor N ortheast Bank Interview, supra note 64 (transcript at 4).

116. See supra pp. 423-423 (discussing the choice businesses make between letter-of-credit transactions and documentary-collection transactions).

117. See supra note 75 (reporting data on that point). 
credit transactions about 100 times smaller, on the order of one tenth of one percent.

Thus, the bank must assert something tied more directly to the letter-of-credit transaction, probably a general prediction that the buyer will perform according to industry norms in the letter-of-credit transaction.118 That prediction - and the parties' need to get the prediction from the bank - rest on two distinct features of the issuing bank's relations with the buyer. The first is the essentially predictive point discussed above: the bank's ability based on its past interactions with the buyer to assess the buyer's general probity. The second is a leverage-related point: the bank's understanding that it can influence the buyer's behavior on the particular question at issue, the buyer's willingness to waive discrepancies. However unconstrained the buyer's legal right to reject the documents may be, the buyer will often disappoint the bank if the buyer rejects documents that include discrepancies that normally would be waived in the industry in question.119 And if the buyer knows that the bank will be "disappointed" by the buyer's conduct, the buyer may refrain from the conduct absent dire countervailing pressures. ${ }^{120}$ From the perspective of the seller, the ability of the bank to influence the conduct of the overseas buyer might comprise the most important aspect of the letter of credit.

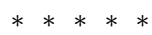

In sum, in addition to the classic explanation - that the issuer will pay in those cases in which the seller presents compliant documents - I posit a second explanation - that the issuer is confident based on past experience or its expectation of future leverage that the buyer "voluntarily" will choose to pay whether or not the documents comply. That explanation, however, doesn't carry equal weight as a general explanation for the use of letters of credit in transactions exporting goods into the United States. In inbound transactions, sellers have access to a considerable amount of apparently reliable information about the buyers in question, particularly the large retailers that were prominent in the data. ${ }^{21}$

Certainly, many overseas exporters have similar concerns about the reliability of their A merican customers, but the explanation presented in this section does not

118. See supra notes 111-112 and accompanying text (discussing evidence suggesting that banks would stop dealing with customers that refuse to follow industry norms in waiving discrepancies in presentations on letters of credit).

119. The ready willingness to impose nonlegal sanctions on a trading partner for insisting upon something that is entirely lawful reminds me of the sanctions that $L$ isa Bernstein discusses for "laying down on a contract" in her discussion of the cotton industry. See Bernstein, supra note 1, at ????-????. I have no firm answer for the deeper question - why does the bank sanction the buyer that refuses payment in a transaction supported by a letter of credit but not in a transaction supported only by documentary-collection arrangements? - but the most likely answer seems to be a general understanding of the issuer that its reputation is on the line for presentations against its letters of credit to be honored, where its reputation is completely disengaged from the results of a documentary-collection transaction. See supra note 74 (reporting the relatively lackadaisical attitude of banks to nonpayment in documentary-collection transactions).

120. See M ann, supra note 14 , at 2261-62 (suggesting that the same analysis is a common justification for guaranties and standby letters of credit).

121. Clay Gillette makes that point well in his comment on this paper. See Gillette, supra note 31 , at m??-???? 
ring nearly as true when the transaction is a purchase by $\mathrm{W}$ al-M art in the $U$ nited States from a small Taiwanese clothing manufacturer for whom it is a major customer, as it does with a one-time shipment of parts from an American manufacturer to a small business in India. A ccordingly, I turn now to assert a plausible explanation for those transactions.

\section{Verifying the A uthenticity of the Transaction}

The second explanation that appeared regularly in my interviews rests on a variety of usages of letters of credit that serve indirectly to ve rify the authenticity of cross-border sales transactions. Because those justifications make sense only in the contexts in which the requirements appear, they are quite local. The most important justification, for example (the governmental requirements in section (a) of the following discussion), appears only in transactions that involve imports into less economically stable countries. Hence, in the sample analyzed here (limited to transactions involving the U nited States) it applies only to export transactions going from the U nited States to such a country.

As with the practice discussed in the preceding section, the letter of credit here serves as a verification institution. Specifically, the government or a trading partner uses a direct or indirect letter-of-credit requirement as a device for limiting the risk of loss from fraudulent or illegal transactions ${ }^{122}$ by taking advantage of the superior informational position of the beneficiary's bank.

a. Governmental Requirements. The most common example is a set of governmental requirements that tend to appear in countries for which either the weakness of the local currency or concerns about money laundering justify substantial currency controls. ${ }^{123}$ The simplest pattern involves bogus sale-of-goods transactions, a common device that wrongdoers use to transfer currency out of a country in violation of applicable governmental rules. The typical scheme uses a transaction in which a party in the currency-restricted country purports to purchase goods from a party in a strong-currency country (such as the U nited States or the European Union). If the price of the goods is inflated - an Indian company buys a dozen tennis balls for $\$ 1,000$ - then performance of the transaction allows the Indian buyer to transmit a large amount of currency into a foreign forum, where the Indian government often has difficulty tracing the funds.124

122. O ne banker commenting on a draft of this paper emphasized the narrow range of the phenomenon, transactions that are themselves illegal. Banks do not undertake, for example, to investigate or verify a manufacturer's compliance with child- or prison-labor regulations.

123. See M idwest Bank Interview, supra note 47 (transcript at 1 ).

124. See M idwest Bank Interview, supra note 47 (transcript at 3-4) (offering that example); see also Foreign Bank Interview, supra note 78 (transcript at 2) (offering a similar example); M ajor N ortheast Bank Interview, supra note 64 (transcript at 8-9) (suggesting that the parties don't even bother to ship goods in those transactions). O ne banker suggested that a similar transaction could be used in reverse on large sales of goods going into a currency-restricted country. The A sian seller could issue an invoice reciting an inappropriately low price; the out-country buyer could pay the invoice directly and transfer the remainder of the actual (noninvoiced) price in hard currency to an account for the benefit of the seller in a secure location. See Foreign Bank Interview, supra note 78 (transcript at 2-3) (discussing that transaction as well-known in sales of goods to mainland China). 
G overnments can use letters of credit to hinder those transactions by requiring the use of a letter-of-credit in substantial cross-border sale-of-goods transactions.125 $W$ ith such a requirement, the government obtains an indirect verification of the legitimacy of the transaction, because the local bank often would not take the risk of participating in a transaction that seemed likely to involve an illicit transfer of funds. Thus, by imposing letter-of-credit requirements, the government indirectly motivates the banks that participate in the transaction to police apparently illicit transactions. ${ }^{126}$

As it happens, few countries impose such absolute requirements.127 Still, governments do use a variety of less direct devices for protecting against such transactions, many of which lead indirectly to the use of letters of credit. F or example, the government could require a letter of credit as a condition of issuing a license in advance of an actual import or export transaction.128 Because overseas sellers might want the buyer to have an advance license to ensure the availability of hard currency to pay for the goods when they arrive, letters of credit are common in such a regime.129

Even less intrusively, the government might insist that all transactions involving the payment of more than a set amount of hard currency overseas must go through a bank. ${ }^{130}$ The government then can require banks that participate in such transactions to verify a number of particular features of the transaction to prevent fraud. At that point, the marginal cost of the letter of credit (over a collection transaction) might become so small as to make it preferable in situations in which the collection transaction otherwise would be preferable. ${ }^{131}$

In yet another variation, least intrusive of all, the country does not insist on letters of credit even to issue the license. But insistence on a letter of credit offers the best option for the overseas trading partner to assure the availability of currency to pay for the transaction, because the local bank will not issue the letter of credit without ensuring that the applicant has obtained the appropriate licenses to allow

125. See M idwest Bank Interview, supra note 47 (transcript at 1 ).

126. It seems clear that bank involvement - however it might be brought about - is ffective in discovering fraudulent transactions. A lthough it is difficult to get data, one banker did tell me that his office detects three to five such transactions each week. See M ajor Northeast Bank Interview, supra note 64 (transcript at 7,9).

127. See M idwest Bank Interview, supra note 47 (transcript at 1-2) (discussing such equirements in Japan after W orld W ar II and their gradual disappearance over the intervening years; citing $M$ alawi and unspecified countries in Latin America as still requiring letters of credit for transactions in certain commodities).

128. See F oreign Bank Interview, supra note 78 (transcript at 1) (offering that scenario). A Iternatively, the government might accept lower deposits for license applications when the transaction has a letter of credit. See M idwest Bank Interview, supra note 47 (transcript at 3-4).

129. See Foreign Bank Interview, supra note 78 (transcript at 1-2) (offering that explanation); M id-Sized N ortheast Bank Interview, supra note 56 (transcript at 4-5) (same); see al so F oreign Bank Interview, supra note 78 (transcript at 3-4 (describing recent series of transactions in which the Chinese government refused to allow Chinese banks to use hard currency to honor letters of credit that they previously had issued, even in transactions for which the banks had obtained the approvals appropriate at the time of the transaction).

130. See M idwest Bank Interview, supra note 47 (transcript at 3-4) (suggesting that India imposes such a requirement for any transaction over the equivalent of five thousand dollars).

131. See M idwest Bank Interview, supra note 47 (transcript at 3-4). 
transfer or the required currency. ${ }^{132}$ That use of the letter of credit protects the seller against the risk that after it ships even a conscientious purchaser (and its bank) will be unable to obtain hard currency to pay the seller for the transaction. In that regime, the government gets the benefit of the letter-of-credit verification without formally insisting that the parties use the letter of credit.

b. Private R equirements. Lenders also use letters of credit in a closely analogous way to verify the authenticity of transactions brought to them by potential borrowers. The typical pattern here is in a so-called "packing" credit transaction, in which a business in a major trading city (Hong Kong, in the most common example) imports goods from one foreign country that it plans immediately to export to a purchaser in a third country. If that business (the "packer") wants to borrow money to fund its acquisition of the goods, or get a letter of credit to facilitate its acquisition of the goods, the packer must convince its local (that is, local in Hong $\mathrm{K}$ ong) bank of the legitimacy of its export transaction.133

A number of bankers explained to me that the letter of credit from the bank for the American importer allows the Hong Kong bank to verify that the entire transaction is authentic. ${ }^{134}$ Essentially, the use of the letter of credit in those transactions rests on the view of the foreign bank that it is harder to fabricate a credible letter of credit from an A merican bank than it is to fabricate a credible purchase order from a large A merican retailer. ${ }^{135}$

Like the transactions discussed above, those transactions reflect use by the trading-center bank of the informational advantage of the importer's bank. That bank's greater facility at understanding its customers' transactions justifies its business of issuing letters of credit in those transactions.

132. See Foreign Bank Interview, supra note 78 (transcript at 1-2) (offering that scenario). One banker explained that in those transactions the parties waive document exam ination at both ends of the transaction and that he never has seen rejection of a presentation against such a credit. See Midwest Bank Site Visit Notes, supra note 44 , at 3.

133. See M ajor N ortheast Bank Interview, supra note 64 (transcript at 3-4); M idwest Bank Interview, supra note 47 (transcript at 9-10); Second Major Northeast Bank Telephone Interview, supra note 44 (transcript at 3); see also Fuji Bank Interview, supra note 44 (transcript at 12) (describing that tran saction as a "switch" transaction).

134. See M idwest Bank Interview, supra note 47 (transcript at 9-10); Second M ajor Northeast Bank Telephone Interview, supra note 44 (transcript at 3-4).

135. See M idwest Bank Interview, supra note 47 (transcript at 10-11); Second M ajor Northeast Bank Telephone Interview, supra note 44 (transcript at 3-4). As one banker explained, in countries that offer interest subsidies for export transactions, the use of a letter of credit can enhance the amount of the subsidy by extending the term of the loan. Because the bank in a packing-credit transaction loans the money to the borrower/ trading company at the time that the ultimate importer provides its letter of credit, the interest subsidy can begin accruing at that time. In a transaction without a letter of credit, the bank nomally would not loan the money until the trading company actually had shipped the goods to the ultimate importer. See Second $\mathrm{M}$ ajor $\mathrm{N}$ ortheast Bank Telephone Interview, supra note 44 (transcript at 4-5). Effectively, that use of the letter of credit transforms a very-short-term transit-financing transaction into a much more useful workingcapital financing transaction. See Second Major Northeast Bank Telephone Interview, supra note 44 (transcript at 4-5). 


\section{CONCLUSION}

The relatively small body of information that I collected cannot provide a definitive view of the letter-of-credit transaction. Nevertheless, it provides a fascinating window to the world of letters of credit. It should not surprise readers of my past work that I cannot convince myself of any single unified explanation of the use of letters of credit.136 Thus, my main goal here is not to explain everything about why businesses use letters of credit. $M$ y goal is less ambitious, to provide information that will initiate the development of a deeper understanding of the sophisticated dynamics of the commercial letter-of-credit transaction. I hope that the data I have collected and made available here will encourage others to look more closely at the problem.

136. See, e.g., Ronald J. M ann, Explaining the Pattern of Secured Credit, 110 HARV. L. REV. 625, 682 (1997) (arguing that no single cause can explain the pattern of secured credit and suggesting a group of positive and negative factors that collectively can explain that patern). 


\section{Statistical Appendix}

Table A displays the results of three bivariate regressions on the data that I collected. ${ }^{137}$ The analysis treats each of the 500 files as an observation; there are only 487 observations because I excluded the files in which the amount of the credit was denominated in a currency other than the A merican dollar. ${ }^{138}$ The dependent variable is the existence of discrepancy, a binary variable that takes the value " 1 " if the file complies and " 0 " if a discrepancy exists. "A mount" is the dollar amount of the entire letter of credit (rather than the single presentation that I studied).139 "Transaction type" divides the 487 files into import-side and export-side files; the variable takes the value " 1 " for export and " 0 " for import. "Bank role" divides export-side files into files in which the beneficiary's bank was an adviser and those in which it was a confirmer, with adviser files taking the value " 1 " and confirmer files taking the value " 0. "

Table A: Bivariate Regression Results

$\begin{array}{lccccc} & N & \text { Coefficient } & \text { R } & \text { t-statistic } & \text { p-value } \\ \text { A mount } & 487 & .000 & .121 & 2.68 & .007 \\ \text { Transaction Type } & 487 & .105 & .119 & 2.635 & .009 \\ \text { Bank Role } & 242 & .049 & .035 & .549 & .583\end{array}$

As Table A shows, the lack of discrepancy correlates with amount weakly, albeit at a significant level. Specifically, the higher the amount, the more likely the file is to comply; the lower the amount, the greater the likelihood of discrepancy. A s I explain above (see supra note 80 ), I think that the most probable explanation for that relation is that parties invest in more careful compliance efforts on larger transactions. ${ }^{140}$

Second, discrepancy correlates highly with the side of the transaction that I examined: more discrepancies in import transactions, fewer in export transactions. The body of the A rticle provides several possible explanations for that relationship, most prominently in subpart III(C). Because the export transactions were larger

137. I owe special thanks to $M$ ark W est for aid on the statistical analysis that goes far beyond the norms of collegiality (but not so far as to imply responsibility for the analysis).

138. Because I do not have the dates on which the letters of credit were issued and honored, it would be difficult to select exchange rates to convert those transactions to dollar amounts. M oreover, even if I did have the dates, it is not clear what date (issuance or payment) would provide the most appropriate exchange rate.

139. To avoid undue reliance on a few files, I only recorded one shipment and presentation from each letter of credit that I examined, even in the (frequent) cases in which a single letter of credit applied to multiple shipments and presentations. U nfortunately, I collected only the gross amount of the credit; I did not collect the amount of the single presentation that I studied.

140. Other explanations are possible, of course. For example, larger transactions might occur in industries that tend to have simpler documentary equirements or practices of more careful documentary preparation. M ore data would be required to evaluate those hypotheses. 
than the import transactions (a correlation that falls just short of significance, at the 0.11 level), it would have been useful to do a multiple regression to ascertain whether size (rather than transaction side) was the important variable. Because both the dependent variable (discrepancy) and one of the independent variables (transaction type) are bounded by zero and 1 , the value of an ordinary least-squares multiple regression of that analysis would be dubious.

Finally, there appears to be no correlation between the bank's decision to confirm the letter of credit and the existence of discrepancy. 